\title{
ESKI TÜRK INANCI ÜZERINE BIR ÖZET
}

\section{Saadettin GÖMEÇ*}

\section{ÖZET}

Eski Türk dini ve Şamanizmin mahiyeti hususu halâ aydınlatılamamış Türklük Bilimi problemleri icerisinde yer almaktadır. Kimse de bunlan ne oldugunu tam manasıyla bilememektedir. Zaman zaman eski Türk dini diye Şamanizm, bazan da Samanizm diye eski Türk dini anlatılmaktadır. Bu çalışmada mümkün olduğu kadar, iki kavramın sınırları çizilmeye çalışılmıştır.

Anahtar Kelimeler: Tanrı, Din, Şamanizm

\section{ABSTRACT}

Religion is path and way of believing, as well as rules adopted within a system of belief. In the early phases of history, the concept of religion began with the admirance of the nations and ethnic groups for super natural powers. In order to understand the basis of the old Turkish religion we should not only researc the Turkish tradition and customs, but also analyse the history in all details.

Keywords: God, Religion, Shamanism

Din; yol, inanç sistemi, bir inancin uyulması gereken kaidelerinin tamamıdır. $\mathrm{Bu}$ mefhum etnik toplulukların ve milletlerin eski çağlarda tabiatüstü güçlere duydukları hayranlıklarla başlar. Eski Türk dininin de esaslarını kavrayabilmek için Türk töresi, ve geleneklerinin araştırılmasıyla beraber, rahmetli A.İnan'ın da dediği gibi, tarihin derinliklerine kadar inmek gerekir.

Bugün Şamanlık olarak bilinen, fakat bizim din adamlarından dolayı Kamlık diyebileceğimiz, eski Türk dini veya Kök Tengri Dini ile Saha (Yakut) ya da Altay Türk inancının bir olduğunu söylemek mümkün değildir. Çok eski zamanlardan itibaren bir devlet geleneğine sahip olan Türklerin dini itikatları, bugünkü Altay ve Saha dini inançlanndan daha gelişmiş düzeydeydi.

Bizde eski Türk dini üzerine ilk ciddi çalışmalan bilindiği gibi Ziya Gökalp yapmıştır. Ona göre eski Türk dinine "Toyonizm"1 veya "Nom" denilmelidir. Nom kelimesi de Tarih-i Cihangüşa'da "Türk dininden olanlara Nomiyan" denilmesine bağlanmaktadır. Yine Cihangüşa'nın bildirdiğine göre, hakan huzurunda Nomilerle Kamlar imtihan olmuşlar ve Nomiler Kamlan mağlup etmişlerdir. Cüveyni Nomilerin "Nom" adll bir de kitaplarından

"Prof.Dr. A.U. Dil ve Tarih-Coğrafya Fakültesi Tarih Bölümü.

'Saha Türkleri Toyon kelimesini "Tann, efe ndi, din adamı" anlamlannda kullanıorlardı (Bakınız, B.Ögel, Türk Mitolojisi, Ankara 1971, s.430-431). 
bahsetmektedir ${ }^{2}$. Bize göre Tarih-i Cihangüşa'da bahsedilen Maniheizm olsa gerek. Çin kaynaklarının bilgilerine göre, Kök Tengri Dini birtakım dini törenlerin muayyen bir düzen içerisinde ifa edildiği bir sistemdir. Hunlardan sonra Türk Devletinin başına geçen Tabgaç sülalesi zamanında da bu inançlardevam ettirilmiş, onlar da baharın ilk ayında kutsal Atalar Mezarlığında Kök Tengri'ye kurbanlar sunmuşlard. Onlar kurbandan sonra kayın ağaçları dikerler, böylece kutlu ormanlar meydana getirirlerdi. Kök Türklerin keçeden ve deriden tözler yaptıkları ve bunları iç yağıyla yağladıktan sonra sıriklara astıkları, yılın dört mevsiminde de kurban kestikleri yine Çin kaynaklarında kayıtlıdır. Merkezleri kutlu Ötuiken olan Kök Türkler, tıpkı kendilerinden önceki Türkler gibi, Kutlu Atalar Mezarlığında kurban keserlerdi.

Tabgaç Türk sülalesi, 4. yüzyılın sonlarına doğru Çin'e hakim olduktan sonra, kendini Çinlilerden ayırabilecek bir dine ihtiyaç duydu. İç Asya'da ve Hindistan'da tamamen hür hareket edebilen Budistleri, bu Tabgaç hükümdarlan himaye ettiler. Kagan kendisini Buda'nın müridi kabul ettiği için, Tabgaç hanedanının da milli dini oldu. Belki Tabgaçlar, Budizmin milli yapılannı zayıflatması sebebiyle Çinlileștiler, ama Tabgaçlar budist sanatta yeni bir devir olan Wei San'atının geliştiricisi oldular. Daha sonra Kök Türklerin meşhur hükümdarı Taspar (Tapar) Kagan da (572-581), Budizmi kabul ederek, Türklerin arasına budistligi yeniden sokmuştu. Kuzey Chou Devletinde, Imparator Wu-ti tarafindan yasaklanan Budizmin ünlü misyoneri Hintli Jinegupta, müritleriyle beraber Kök Türklere sı̆̆ınmış ve burada on yıl kalmıştı. Bu sırada Budizmin bazı ilkeleri öğrenilmekle beraber; birçok dini kitap ve metinler Kök Türkçeye çevrilmiş, budist tapınakları ve manastırları kurulmuştu ${ }^{3}$. Taspar Kagan tahta çıktığında Kök Türk Kaganlığı en kudretli çağında bulunuyordu. Emrindeki ordunun say ssı yüzbinleri geçiyor ve bu kuvvetle Çin'e korku salıyordu. Çin elçileri çeşitli vesilelerle Türk başkentine geldikleri zaman onlara "ogullarım" diye hitap ediyordu. Bilge Kagan da (716734) Taspar Kagan gibi bir hataya düşmüsstü. $O$ da, Türklerin yerleşik hayata geçmeleri için Budizmi kabul etmek ve şehirlerde yaşamak istiyordu. Ancak onun bu düşüncesine dahî devlet adamı Tunyukuk karşı çıkmış, böyle bir durumun Türklerin milli karakterine uymadı̆̆ını söyleyerek, Bilge'yi bu işten vazgeçirmişti. Fakat Budizm, ki Uygur Türkleri Buda'ya "Burkan" diyorlard,, Uygurların yükseliş dönemine kadar ve hatta Uygur Kaganlığı yıkılıp, dağıldıktan sonra bile varlığını devam ettirdi.

Türk Devletinin başına Kök Türk Börülüler (Aşina) sülalesinden sonra, Uygur Yaglakar ailesi geçene kadar Kök Tengri dini Türklerin inanç sisteminin temelini oluşturmuştur. Bu durum, Bögü Kagan (759-779) zamanına değin sürdü. Yazılı kayıtlan ve önemli ilkeleri olan dinler Türklerin bu milli dinine tesir edemediler. Ancak Bögü Kagan devrine gelindiğinde ise işler değişti. An Lu-shan'ın isyanı (755) Çin'de bütün dengeleri degiş̧tirdiği sirada Uygurlar, Çinlilerin yardımına koşmuşlardı. Çin'e giden askerler burada uzun müddet kaldılar. Çünkü Ân Lu-shan'dan sonra da Çin imparatorluğunda isyanlar durmamıştı. Bu yüzden Çin'de bulunan Bögü'nün Lo-yang seferi bilhassa Türk kültuir tarihi bakımından çok önemli olmuştu. Bu

${ }^{2}$ Z.Gökalp, Türk Medeniyeti Tarihi, Haz. K.Y.Kopraman-İ.Aka, Ankara 1976, s. $40-41$

${ }^{3}$ S.Gömeç, Kök Türkçe Yazlı Metinlerin Türk Tarihi ve Kültürü Açısından Değerlendirilmesi, Doktora Tezi, Ankara 1992, s.25. 
sefer sırasında o, resmen Mani itikadını kabul etti. Uygurlann Moçak dedikleri dört mani rahibini de beraberinde Uygur başkentine getirdiler. Bundan sonra Karabalgasun şehrine bir mani mabedi yapıld. ${ }^{4}$. Mani inancının Türk hayatında yararları olduğu gibi zararları da oldu. Özellikle Türklerin savaş̧̧ılık ruhunu köreltti.

Bununla beraber bütün Türklerin Maniheizmi kabul ettiğini de söyleyemeyiz. Bu inanç ancak yönetici sınıf arasında yayılmış olmalıdır. Cünkü Uygur dönemi yazıtlarından olan Karabalgasun Kitabesinde bu itikadın Türkler arasında yeterince yerleşmediğini gösteren işaretler mevcuttur. Mani metinlerinden anlaşıldığına göre, bu inanış Bögü Kagan ile onun ailesinin cevresinde bir saray dini olarak gelişmiş, Türklerin çoğunu kazanamamıştı. Türkler hem bu dinden, hem de Bögü Kagan'dan çekinmişlerdir. Bu inancin bazı şekillerinin Türklerin milli bünyesine uymadığı ortada idi, ama baş din adamı durumunda olan kagana da kimse karşı çıkamıyordu. Maniheizme göre, herkes birgün içinde yalnızca akşamları yemek yemelidir. Suya saygı göstermek lazımdır. Süt katiyen içilmemelidir. Tereyağı yemek yasaktır. Hatta Mani mezhebinin büyük rahipleri yerlerinden birkaç sene kımıldamıyorlardı. Küçükleri ise, durmadan gezerlerdi. Maniheizmin biri farsça, altı tanesi süryanice olmak üzere yedi kitabı vardı. Mani itikadı bir tücçar ve şehirli diniydi. Mani inancının savaş̧̧ı ruhları yumuşattığı da doğrudur ${ }^{5}$.

Çin ve İslam kaynaklarına göre Uygurlardan sonra yönetimi ele geçiren Kurgızlar da Kök Tengri'ye inanıyorlardı. 11. yüzyılda Hazar ile Aral arasında yaşayan Oguzlar üzerinden İtil Bulgarlarına giden İbn Fadlan'ın malumatında ıse Oguzlar da eski Türk dinindendiler. Ölü gömme merasimleri aynı Kök Türklerinkine benziyordu. Balbal dikip, yog törenleri yapıyorlardı. Yine İbn Fadlan, Başkurtların gökte yaşayan en büyük tanrıya inandıklarını söylemektedir ${ }^{6}$.

\section{a-Şaman}

Saman kelimesinin etimolojik kökeni üzerinde şimdiye kadar çok durulmuştur. Bu terimin Tunguzcadan rusça yolu ile Batı ilim dünyasına gectiği billinmektedir. Aslen Sanskritçenin bir koluna bağli olduğu sanilan kelimenin, Hind-Avrupa dillerinden Toharca (Samane=budist rahip) ve Sogdçadaki (Saman) transkripsiyonları keşfedilince, bu terimin Hind-Avrupa menşeili olduğu görüşüu kuvvet kazanmıştır. Çünkü bu kelime Tunguzcaya yabancl görünmekte ve Samanlığın güneydén kuzeye doğru yayıllışnda Budizmin tesiri sezilmektedir. Fakat Tunguzların komşuları olan Sahalara etki ettikleri de bir gerçektir ${ }^{7}$.

${ }^{4}$ R.Grousset, Bozkır İmparatorluğu, Çev. R.Uzmen, İstanbul 1980, s.130; B.Ögel, Islamiyetten Önce Türk Kültür Tarihi, 2. baskı, Ankara 1984, s.349-350; L.Rasonyi, Tarihte Türklük, 2. bask1, Ankara 1988, s.106.

${ }_{5}^{5}$ S.Gömeç, Uygur Türkleri Tarihi ve Kültürü, Ankara 1997, s.80-81.

${ }^{6}$ İbn Fazlan Seyahatnamesi, Haz. R.Şeşen, İstanbul 1975, s.36.

7 A.İnan, Tarihte ve Bugün Şamanizm, 2. baskı, Ankara 1972, s.74; S.Buluç, "Saman", İslam Ansiklopedisi, C. 11, 2. bask1, İstanbul 1979, s.310-311; H.Tanyu, "Şamanlık veya Şamanizm", Türk Ansiklopedisi, C. 30, Ankara 1981, s.203; L.Rasonyi,

Tuna Köprüleri, Çev. H.Akın, Ankara 1984, s.13. 
Hakikaten eski Türk topluluklarında Şamanlığa benzer bir inancın varlığına ihtimal verdirecek hiçbir kayıt mevcut değildir. Altay Türkleri tarafindan bugün Saman manasina "Kam" sözü kullanilmakta ve bu kelime bilindiği kadarıyla 5 . yüzyıldan beri yaşamaktadır. Avrupa'da hakimiyet kuran Hunlar zamanında Ata-kam ve Es-kam adlarında iki kişıden bahsedilmektedir. Yani Avrupa Hunlarının din adamlarına da Kam denilmekteydi ${ }^{8}$. Eğer eski Türklerde şamanlık olsaydı, Hunların örf ve adetleri hakkında oldukça geniş, bilgiler veren Latin ve Germen yazarların "Hunların dini törenleri yoktu" diyecek yerde, garip ayinleri olan şamanik telakkilerden haber vermeleri gerekirdi.

Hükümdar ailesinin Budizmle yakın il gisine rağmen, Tabgaçlarda da Şamanlığı hatırlatan birşey yoktur. Hem Budizmi, hem de Maniheizmi kabul etmiş olan Uygurlar da bile bu hususta açık bir delile rastlanılmamaktadır. Hatta Uygurlarda kam sözü din adamı değil, "büyücü, sihirbaz" manalarında kullanılmıştır. Kaşgarlı Mahmud, "kam" sözünü kahin kelimesiyle açıklamıştır. Bu söz o zamanki müslüman Türkler tarafından da unutulmamiştı. Yusuf Has Hacip ise, Kutadgu Bilig'de kamlan "otacılar" olarak çevirmekle beraber, bunların insan toplulukları için faydalı kişiler olduğunu söyler. Kanaati temsil eden Odgurmuş hakana nasihat verirken; "bazı insanlar yoksul, bazı insanlar da kaygı ile yıpranmışlardır. Bunlarm ilacı, dertlerine derman sendedir. Bunlar tedavi et, bunlarin kamı ol" demektedir ${ }^{9}$. Din adamı manasına Türk boyları arasında değişik adlandırmalar vardır. Mesela Kazak ve Kırgızların Kam yerine Baksı, eski Karlukların da Sagun kelimesini kullandiklanın biliyoruz. Baksı herhalde Budizm vasitasıyla gelmiş yabancı bir kelime olmalıdır. Türkmenlerde bakşı veya baksı "saz şaıri". manasını ifade eder. Altaylılar ve Tuvalılar bugüne kadar kam kelimesini yaşatmışlardır. Saha Türkleri erkek kama "oyun", kadın kama "udagan" derler. Mogolcada erkek kam "bö" yahut "böge", kadın kam da Sahalar gibi Udagan adını alır. Çuvaşlar da ise bu kelime "yum"dur. Müslüman Türkler kam kelimesini unutmuşlardır. Şaman kelimesini Türkler bilmez. 18. yüzyılın sonlarına doğru kabul edilmiş olan "şaman" terimi Türkçeye yabancıdır 10 . Orkun kitabeleri de dahil olmak üzere, şimdiye kadar bulunan kitabelerde ne Kam sözüne, ne de Samana tesadüf edilmiştir. $\mathrm{Bu}$ nedenle, mevcut vesikalardan yola çıkarak, Eski Türkler Şaman idiler şeklinde bir sonuçta çıkarılamaz.

\section{b-Şamanizm}

19. yüzyılın 2. yarısında Orta Asya Türkleri arasında araştırma yapan W.Radloff, V.Verbitsky, A.Anohin gibi Ruslann tesbitleri sonucunda eski Türk dininin ana vasfında Şamanlık varmış gibi bir düşünce hasıl olmuştur.

${ }^{8}$ Ínan, a.g.e., s.72; İ.Kafesoğlu, Eski Türk Dini, Ankara 1980, s.40; P.Vaczy, "Hunlar Avrupa'da", Attila ve Hunları, Yay. G.Nemeth, Ter. Ş.Baştav, Ankara 1982, s.105. Kam kelimesi Divanü Lûgat-it- Türk, Kutadgu Bilig ve Turfan Metinlerinde de geçmektedir.

${ }^{9}$ Kutadgu Bilig İndeksi, Istanbul 1979, s.218; Kaşgarlı Mahmud, Divanü Lûgatit-Türk Dizini , Ankara 1986, s.257.

${ }^{10}$ W.Radloff, Sibirya'dan Seçmeler, Çev. A.Temir, Ankara 1975, s.301-302; İnan, a.g.m., s.74-75; Kafesoğlu, a.g.e., s.40-41; L.Rasonyi, Tuna Köprüleri, Çev. H.Akın, Ankara 1988, s.12. 
Bugün Asya Bozkırlarındaki dini inançların Şamanlığa bağlanması adet haline gelmiş gibidir.

Günümüzde eski Türk dininin geleneklerini yaşatan Türklerin kozmogonisine göre, esas itibarıla tanrılarnn en yükseği, insan oğullarının atası olan Tengri Kayra Kan (veya Bay-Ülgen) kişiyi ve bunun aracılığıyla yeryüzünü yaratmış, kişinin kendisiyle mücadeleye girmesi üzerine ona Erlik adını vererek, ışı diyarından, yeraltına atmış ve yerden dokuz dallı bir ağaç büyüterek, her dalında bir cins insan türetmiştir. Altay yaradılış destanlanndan birisinde, Tann insanın kulaklarına üfleyerek can, burnuna üfleyerek de akl vermiştir ${ }^{\prime \prime}$. Bu motiflere başka hiçbir efsanede rastlanılmamaktadır. Kamlık inancina göre kainat üst-üste katlardan müteşekkildir. Bu katlar belirli bir düzen üzere birbirlerinden ayrılmışlardır. Bundan dolayı Kam san'atını icra ederken, bir kattan diğerine geçmek için büyük bir güç sarfetmek zorundadır. Yukanda onyedi kat vardır ve ışık alemini teşkil eder. Aşağıda yedi veya dokuz kat bulunur. Bu da karanlıklar dünyasidır. Insanlar da bu iki alem arasında, yani yeryüzünde yaşarlar. Koruyucu ve iyi ruhlar bu sşı diyarında bunurlarken, gögüun en üst katında ise, altın bir taht üzerinde, dokuz erkek ve dokuz kızı ile beraber Bay-Ülgen oturmaktadır ${ }^{12}$. Insanları, hayvanları, bitkileri, dağları, ırmakları, gölleri, denizleri, ayı, güneşi ve yıldızlan yaratan odur. Kırgız ve Kazak lehçelerinde "Ülgen" büyü̈k ve ulu anlamlarını ifade eder. Ülgen iyilik eden bir varlıktır. Onun huzuruna giden yolda yedi engel bulunur. Onun yanına giden yol ancak erkek kamlara açıktır. Bununla beraber erkek kam beşinci engele kadar, yani Temir Kazık yıldızına gidebilir ve oradan geri döner. Bir inanışa göre, Saha Türklerinin tarihinde yalnız bir Oyun dokuzuncu kata ulaşmış ve bugüne kadar da geri dönmemiştir ${ }^{13}$. Bugünkü Altaylılara göre, Erlik yerin en altında, kara çamur veya kara demirden sarayda, kara taht üzerinde oturur. Kötülüŭüun kaynakları da yerin altındadır. Bunlara Altay Türkleri tarafından kara-töz (kötü ruh), kara-neme (kötüi nesne) veya tümengi töz de denilir. Altaylllar en büyük felaketleri, salgın hastalıklan ve hayvan kurginlarin Erlik'ten bilirler. Erlik'e giden yolda da tipkı, Ülgen'inki gibi engeller vardır ve bunlara "pudak" (budak) derler. Erlik de yedi veya dokuz çocuğ sahiptir ${ }^{14}$.

"Daha insan yaratılmamışken, Ülgen deniz üzerinde yüzmekte olan ve insana benzeyen bir çamur tabakası görür. Bu çamur yığınım alarak insan olmasını ister. Ülgen ilk yarattı̆ına Erlik adını verir. Başlangıçta Ülgen'e dost ve kardeş gibi görünen Erlik, bir süre sonra kendini onunla bir tutmaya ve hatta üstün görmeye başlar. Gün geçtikçe Ülgen'den her bakımdan uzaklaşır ve onun yarattıklarının hepsine düşman olur (Bakınız, A.M.Sagalayev, Altay v Zerkale Mifa, Novosibirsk 1992, s.23).

${ }^{12}$ Ögel, Türk Mitolojisi, s.446; İnan, a.g.e., s.72; Radloff, a.g.e., s.214-216; Kafesoğlu, a.g.e., s.22-23. Altay Türklerinden olan Lebedlere göre Ülgen'in 4 oğlu vardır. Bu dini hikayelerde Ülgen'in ve Erlik'in kızlarından ve oğullarından bahisler varken, eşleri hakkında pek bir şey söylenmemesi de ilgi çekicidir.

${ }^{13}$ F.Fedotoviç, "Saha Yeri ve Saha Türkleri", Çev. S.Gömeç, AÜ. DTCF. Tarih Araştırmaları Dergisi, 16/26, Ankara 1994, s.238.

${ }_{14}$ Mesela Altaylarda anlatılan bir şaman hikayesine göre; Erlik'in oğlu Temir-kan'a şamanlardan birisi şöyle bir seyahat yapmışır: Önce şamanın ruhu yeryüzündeyken bir dağm tepesine uçar. Bu suretle o iyi ruhlara kendini ve evini koruması için dua eder. Daha sonra yer altına dalar. Burada onu ahlakları hiç de iyi olmayan Erlik'in kızlan bekler. Günahtan kurtulunca yolu çöl gibi dümdüz bir yerden geçer. O ruhuna sahip olmak isteyen beş keçinin bulunduğu büyük bir bataklığa yaklaşır ve sonra intihar edenlerin, kendini yaralayanlann kanlanndan oluşmuş bir göle yaklaşır. Gölü geçtikten sonra, şamanın ruhu kamladığı ailenin 
Fakat bunlan bir kenera bırakıp, Türklerin türeyişiyle ilgili rivayetlere Cin kaynaklarının yardımıyla şöyle bir bakacak olursak; "herşeyin sahibi olan Tann birgün yukarıda mavi gökleri yarattı. Sonra bu muazzam uzay boşluğu içerisine dünyaları yerleştirdi. Önce göğü, sonra da yagız-yeri yaratmıştı. Bütün bunlara rağmen eksik olan birşey vard ${ }^{15}$. Bu yaratmış olduğu evrene öyle birşey eklemeliydi ki, hem kendisinin yarattıklarının en üstün varlı $\breve{g}_{1}$, hem de bu dünyanın bir anlamı olmalıydı. Böyle düşünürken kendisinden de birşeyler kattı̆̆ı insanı vücuda getirdi. Ve "yukanda mavi gök, aşağıda yagız yer kılınmış; ikisinin arasında da insan oğlu yaratılmıştı". Fakat Tann, insanları farklı farklı yarattı. Onlan çeşitli ırklara, kabilelere böldü. O, insan ırklarının bu şekilde birbirlerini tanımalarını ve karışmamalarını istiyordu.

Binlerce yıl geçtikten sonra insan oğlu yeni yeni şeyler öğrendi, başka başka özellikler kazand. Irklar zamanla birbirlerinden tefrik edilmek için çeşitli adlar almaya başladılar.

İşte bunlardan birisi vardı ki, o zamana kadar yaratılmış olan hiçbir ırka, hiçbir soya benzemiyordu. Tanrı, bu rka o vakite kadar meydana getirdiği hiçbir soyda olmayan meziyetler ve hünerler bahşetti. Bu 1 rk dünyanın en savaş̧ıı, en zeki, en dürüst, en güzel ahlaklı ıkıydı. Bulunduğu coğrafyada ona korkuyla karışı bir saygı hissi vard. Bu ırk zayıfların ve haklıların koruyucusu, zalimlerin ve haksızlanın düşmanıydı.

Yukarıda her ırkın kendini diğerlerinden ayırmak için adlar almaya başladığını söylemisstik. O zamanlar, bahsetmiş olduğumuz bu ırkın başında tıpkı kendisi gibi çok cesur, yiğit ve akıllı bir kişi vardı. Herkes onun sözünü dinler, yap dediğini yapar, yapma dediğini yapmazdı. Bu kişinin adı Türk'tü. Türk "güç, kudret, erdem" demekti. Onun soyundan gelen kişiler de bu özelliklerinden dolayı o öldükten sonra, bu adı almayı uygun buldular.

Türk'ün yeryüzünde bu kadar sevilmesi, bu ırkın üstünlükleri yüzünden dünyada bazı ayncalıklara sahip olması, çevredeki toplumların ve ülkelerin bazılarının ona düşman olmasına sebep oldu. Onun bu düşmanları aralarında gizli planlar yaparak; Türk milletini birgün tuzağa düşürerek büyük bir bozguna uğrattılar. Bu korkunç baskından bir çocuk haricinde kimse kurtulmamıştı. Düssman askerleri bu çocuğu öldürmemişler, fakat kol ve bacaklarını keserek bir bataklığa atmışlardı.

geleceğinden haberdar olur. Arkasından delikli bir taştan geçerek, dipsiz kara bir göle ulaşır. Gölün üzerinde bir at kılından köprü vardır. Şaman buradan da geçip, ölen atalarının yaşadığı bir yere varır. Bu kez de Temir-kan'ın kızlanyla karşılaşır. Onlar da bunu günaha sokmak isterler, fakat şaman aıtık hedefine ulaşmıştır. Karşısında Temir-kan'ın çadırn durur (Bakınız, Sagalayev, a.g.e., s.52-56)

${ }^{15}$ Günümüz Altay Türklerinin inanışına göre; daha ne yer, ne de gökyüzünün olmadığ bir sırada Ülgen dünyayı nasıl yaratsam diye düşünür. Bu esnada yanına Erlik gelir ve dünyayı yaratmak için gerekli malzemeyi nereden temin edebileceğini söyler. Kendisinin bile aklına gelmeyen şeyi bulduğu takdirde kızmayacağını belirtir. Erlik (veya kişi) suya dalarak, ağzında bir toprak parçasıyla su yüzüne çıkar. Ülgen bu toprağı serperek dünyayı meydana getirir. Fakat getirilen toprağın bir parçası Erlik'in dişleri arasında kalır ve Erlik onu Ulgen'in yarattı̆̆ dünyanın üzerine tükürür. Böylece dağlar, bataklıklar ortaya çıkar (Bakınız, Sagalayev. a.g.e., s.24) 
Yeryüzünde olup-biten bu işleri Tanrı makamından seyrediyordu. Kendi yaratmış olduğu, bu kutlu ırkın yok olmasına razı olmadı. Onun için bu çocuğun yanına bir dişi kurt gönderdi. Bu dişi börü, çocuğa et ve yiyecek getiriyordu. Bunlarla beslenen çocuk ölümden kurtuldu. Biraz büyüyen bu çocuk kurtla birleşti ve kurt onḑan gebe kaldı. Etrafta kurt gibi yaşayan bir çocuğun olduğunu duyanlar, onu öldürmeye geldikleri zaman, kurt Tann'dan gelen buyruğu dinleyerek, çocukla birlikte yaşadıklan göl kıyısının kuzeyinde bulunan bir dağa kaçtı. Bu dağın içerisinde çok büyük bir mağara vardı. Börü çocuğa yol göstererek mağaranın içerisine girdi. Ortasında otları, ağaçları, nehirleri ve gölleri olan bir ova bulunuyordu. Bu ovanın genişliği onlarca km_ idi. O kadar güzel bir yerdi $\mathrm{ki}$, Tann bu Türk çocuğunu adeta cennetin dünyadaki bir eşi olan bu yere özellikle getirmişti. Onun burada çoğalmasını, güçlenmesini ve yeniden kendi adaletini uygulamasını istiyordu. Börü burada on erkek çocuk doğurdu. Bu on çocuk büyüyünce, bu dağı binbir güçlükle geçip, on tane kız kaçırarak buraya getirdiler ve burada çoğaldılar. Bunlardan birısı kendisine Börü (Aşina) soy adını alarak, çadırının önüne kurt başlı bir sancak astı. Daha sonra bunların hepsinin başı oldu.

Aradan yıllar geçti, Türkler buraya sı̆̆maz oldular. Artık Ergenekun (Kunların çogaldığı, ergenleştiği yer-Halkın çoğaldığı yer) adı verilen bu kutlu yurttan çıkmak gerekiyordu. Çünkü onlar yillarca atalarından çeşitli hikayeler dinlemişlerdi. Yaşadıkları, çoğaldıkları bu yurdun dışında bir zamanlar atalarının hükmettiği çok genış ülkeler vardı. Burada durup, oturmak onlara yakışmazdı. Türk'ün yaradılışının bir gayesi bulunuyordu. $O$ sadece ok çekip, kılıç sallayan bir kavim değildi. Tanrı onu yeryüzünde adaleti ve düzeni sağlasın diye göndermişti. Dürüstlüğü n ve iyi ahlakın timsali olması için vazifelendirmişti. Bu görevlerini icra etmesi için yeniden dünyanın içı̉ne dalmalıydı. Fakkat buna bir engel vardı. Bu geniş ovadan çıkmanın bir yolunu bilmiyordu. İçlerinden akıllı bir demirci çıkıp, kendisinin bir planı olduğunu söyledi. O, dağın bir yerinde demir madeni olduğunu ve burayı eriterek dişarı çıabileceklerini söylüyordu. Buna herkes yürekten sevindi. Çoluk-çocuk, yaşlı-genç herkes elinden geldiğince çalıştı. Kimi odun toplayıp-yı̆̆dı, kimi körük dikti. Dağın birçok yerinde sıra sıra kömür dizildi. Yamaçların sağınasoluna bir sira odun, bir sira kömür kondu. Dokuzyüz deve derisinden yapilan köruikler çalıștı; en yaşlı Türk odunları ateşledi ve ellerini göğe kaldırarak ulu Tanrı'ya yalvarmaya başladılar. Tann yeryüzüne göndermiş olduğu bu kavmin dualarını işitti. Demir dağ eridi. Türkler hep bir ağızdan 'Tanrı Türk'ü korusun" diye bağırıyorlardı ve O'da yeryüzünün efendisi bu kavmi esirgedi. Yol açıldı. Ancak onların bu günü unutmalarına imkan yoktu. Bu kutlu gün bayram ilan edildi. Hayatlarının yeniden başlangıcı, yeni yılın ilk günü olarak kabul gördü. Bütün Türk boyları yaşadıkları müddetçe bu günü unutmadılar. Ergenekun Bayramı denilen bu günde çeşitli oyunlar, eğlenceler ve spor müsabakaları düzenledikleri gibi, atalarının yeniden çoğaldıkları bu yere her sene giderek kurbanlar kestiler. Buraya "Ata sini" yani "Kutlu Atalar Mezarlı̆̆ı" adını vererek, orada kurultaylar düzenlediler. Yeni yılı karşılarken, burada merasim yaptılar, hanedanlar devletin başına geçerken halkın da katıldığı, kaganlık seçimlerini burada yaptılar" ${ }^{16}$.

"S.Gömeç, "Ergenekun Yurdun Adı", Meslek Hayatının 25. Yılında Prof. Dr. Abdulhalûk M.Çay Armağanı, C. I, Ankara 1998, s.451-454. 
Her toplulukta olduğu gibi, Türklerde de Hak dinlere girmeden önceki bazı gelenek ve görenekler yeni mensubu oldukları dinin içerısine şu veya bu şekilde sokulmuştur. Bunlar o dinin tesirine uğrayarak günlük hayatta sanki, dinin gereğiymiş gibi yorumlanır. Yani dinler bulundukları etno-kültür ortamın aktif etkisinde kalarak bazı karakteristik özellikler alır. Semavi dinlerin ve geleneksel inançları birbirine karışması neticesinde çoğu eski örf ve düşünceler yeni manalar kazanır. Bunun gibi, dünyanın ve insanın yaradılışıyla ilgili rivayetlerin hemen hepsi Şaman olduğu söylenen Türklerin kendi düşüünceleri değildir. Bunlar çeşitli dinlerden gelen tesirler neticesinde karışarak ortaya cıkmıştır. Halbuki dünyanın yaradilışı Orkun kitabelerinde çok açı bir şekilde izah edilmektedir: Uze kök tengri asra yagız yer kılundukta ikin ara kişi oglı kılınmış̧ ${ }^{17}$. Rivayetlerde geçen özel isimlerin birkaç tanesi müstesna yabancı menşeilidirler. Araştırmacıların belirttiğine göre bu hikayeler Hint, Iran, Yunan, Yahudi efsaneleriyle, belki de Kök Tengrı dininin iç içe girmesiyle, Mogol devrinde ortaya çkan birtakım hikayelerden doğmuştur. Bunların arasından Altay ve Saha Türklerinin gerçek inançlarını ayıklam ak çok zordur.

Bugünkü Altay ve Saha Türklerinin inancında "Tufan Efsanesi”nin çeşitli varyantları mevcuttur. Altay Türklerine ait Tufan efsanesini ilk defa rahip Verbitskiy tesbit etmiştir. Bu rivayetlere göre Tufan'dan önce yeryüzünün hakimi Tengiz Han idi. Bu zamanda Nama adlı meşhur bir adam vardı. Tengri Ülgen buna Tufan olacağını, insanlan ve hayvanları kurtarmak için bir gemi yapmasını söyledi. Nama'nın üç tane oğlu bulunuyordu. Oğullarna gemiyi inşa etmelerini söyledi ve Ülgen'in öğrettiği biçimde bir gemi yapıldı. İnsanlar ve hayvanlar gemiye alındı. Gök yüzünü sis kaplayıp, yerin altından sular fışkırmaya başladı. Gökyüzünden de yağmur yağıyordu. Bir müddet sonra sular çekilip, kara parçaları su yüzüne çıktı. Nihayet gemi bir dağın tepesinde karaya oturdu. Suyun derinliğini öğrenmek için Nama kuzgun, karga ve saksağanı gönderdi, fakat bunlar dönmedi. Bunun üzerine güvercini yolladı ve güvercin gagasında bir dal ile geri döndü. Nama daha önce gönderdiklerini görüp görmediğini güvercine sordu. Güvercin üçünün de bir leşe konup gagaladığını söyledi. Nama onlara kıyamete kadar les ile beslensinler diye bedduada bulundu. Tufandan sonra Nama, "Yayık Han" adıyla tanrilar arasina girdi. Bir başka Altay rivayetine göre, yer yaratılmadan önce su vard. Ülgen birgün suya bakarken, üzerinde yüzen bir toprak parçası gördü. Bu toprağın insan vücuduna benzeyen bir yapısı vardı ve buna "kisi olsun" dedi. Toprak da derhal insan oldu. Ülgen buna Erlik adını verdi. Erlik bir müddet gectikten sonra, Ülgen'den daha büyük ve kudretli olmak istedi. Nihayet Ülgen'e düşman oldu. İnsanlar da ağaç dalındaki meyveler gibi bitti. Buradan eski Türk inancında mevcut maddelere ş̧ekil vermenin olduğu açıkça ortaya çıkmaktadır. Fakat yoktan var etme ise, her halde Samî dinlerden girmiş olmalıdır.

G.Potanin tarafindan tesbit edilen bir Tuva hikayesinde yer bir kurbağanın üzerindedir ${ }^{18}$. Kurbağa kımıldarsa Tufan olur. Eski zamanda bu kurbağa bir kere kımıldamış ve denizler dalgalanarak ulu Tufan olmuştur. Bu tarafi, 2-3

${ }^{17}$ Bakınız, Köl Tigin Yazıtı, Doğu tarafı, 1-2. satır; Bilge Kagan Yazıtı, Doğu

${ }_{18}$ Saha Türklerine göre de; dünya Baykal Gölü içinde yaşayan büyük bir balık üzerinde dururdu. Bu kutsal balığa Sahalar Aragıt Balık derlerdi (Bakızınız, Ögel, a.g.e, s.472). 
felaketi evvelden sezen bir ihtiyar, demir çivili sal yapmış ve bununla insan nesli ile hayvanları kurtarmıştır. Yine Ảnohin tarafından kaydedilen bir rivayette, Tufan olacağını "temir boynuzlu kök teke" haber vermiştir. Bu teke yedi gün dünya çevresinde dolaşmış, acı acı melemiş, yedi gün deprem olmuş, yedi gün dảğlardan ateş fişkırmıştır.

- Yayık Han'ın gemisinin son durağı Altay Türklerine göre, Altay Dağlarının birisidir. Fakat her Türk boyu kendi dağlarını göstermektedirler. $\mathrm{Bu}$ Tufan efsanesi de Türklere daha sonra Sami dinlerinden girmiştir ${ }^{19}$.

Altay Türkleri, birgün dünyanın sonunun geleceğine inanırlar. Bu gelecek son güne, yani kıyamete "kalgancı çak" derler. Türkiye Türkçesinde karşılığı kalacak olan çă̆ demektir. Kıyamę inanışına göre, birgün insanlar çok azacak, günahtan korkmayacaklar ve kötülükler alıp başını gidecek. İyilik ilahı Ülgen bu kötü insanlardan uzaklaşacak ve Erlik yeryüzüne yaklaşacak. Dünyada iyi gücler ile kötü güçler savaşa tutuşacaklar. Milyonlarca insan ölecek. Nihayet bir Ülgen kalacak ve o "ölüler kalkın" diy e bağırınca, bütün cesetler yeniden dirilecek.

Teleüt Türklerine göre; "kalgançı çak" geldiğinde gök demir, yer sarı bakır olur. Hükümdarlar birbirleriyle savassir, halklar kötülük düşünmeye başlar. Sert taşlar ufalır, katı ağaçlar kırılır. Insanların boyu bir dirsek kadar kısalır. Oğul babayı, baba ogulu tanımaz. Telenguitlerde de buna benzer rivayetler anlatılır. Bu zaman geldiğinde töre bozulur, tepeler çalkalanır, demir üzenginin dibi delinir, çuvaldızın deliği yırtılır. Toplumun düzeni bozulur ${ }^{20}$.

Eski Türklerin de birtakım kutsal saydığı nesneler bulunmaktadır. Bunlar "Kutlu Atalar Mezarlığı" olduğu gibi ${ }^{21}$, zaman zaman büyük bir dağ veya ırmak da olabiliyordu. Hunlar, Çin ile yaptıkları andlaşmalan Hun-dağı denilen bir dağın tepesinde kurban keserek teyit ederlerdi. Asya'nın başka kavimleri de bu Türk adetlerini almışlardır. Altaylı Şor ve Beltirler de kurbanlarını Kök Tengri’ye yüksek dağ tepelerinde sunarlardı. Fakat bunların hiçbiri Şaman özelliklerini yansıtmaya yetmemektedir. Mesela, Kök Türkler yılın 5. ayının ikinci yarısında Tannya Kutlu Atalar Mezarlığında kurban takdim ediyorlardı. Cüveynî tarafından bildirilen bir Uygur efsanesine göre, Uygurların saadet ve bolluk sağlayan kutlu dağlan vardı. Bu dağa Kut-tag denirdi. Bu dağ Çinliler tarafından parçalanıp götürüuldükten sonra, Uygurlar felakete uğramışlardır. Bugünkü Mogolistan'da Karabalgasun harabelerine yakın Erdene-Ula hakkında da aynı hikayeler anlatılır. Bunlar, bereketli eski Türk yurtlarının Cinliler tarafından işgal edildiği çağların izlerini taşır. Eski Türkler dağların Tanrı makamı olduğuna inanırlardı. Yüksek dağ tepelerinin

19 Bir rivayete göre; Tufan'dan sonra yer o kadar yumuşamıştır ki, pehlivanları kaldıramamış ve onların vücutlan olağanüstü yükseklikte dağlara dönüşmüşsür (Bakınız, Sagalayev, a.g.e., s.65).

1) Inan, a.g.e., s.22-25

${ }_{21}$ Şine-Usu Yazıtına göre 748 yılında, Uygurlar Atalar Mezarlığında yaptıkları bir kurultay ile Türk devletinin başına geçmişler dir. Bakınız, Gömeç, a.g.t., s.119. Mesela Kök Türklerden önce Çin'de 16 Devlet diye adlandırlan dönemde ortaya çıkmış olan bir Türk hanedanlığı, Kuzey Liangların (M.sonra 4. yüzyıl) hükümdarlarının Altun Dağların doğusunda kurban merasimi düzenlediklerini kaynaklardan ögrenmekteyiz. Bakınız, G.Z.Tang, Çince Kaynaklara Göre Kuzey Liang Hun Devleti'nin Siyasi, Küitürel ve Ekonomik Tarihi, Yüksek Lisans Tezi, Ankara 1999, s.31-32. 
göklere yakın bulunması, uzaklardan mavi renkte görünmesi bu inancın yerleşmesine sebep olmuştur ${ }^{22}$. Mesela eski Türklerin en kutsal dağı Ottüken'in "Iduk-başı" idi. Bu günkü Altay Türklerinin hepsince de Altay en kutlu dağdır ${ }^{23}$.

$\mathrm{Bu}$ aylu kündü Ayas kanıbıs!

Agaç taştı Altayıbıs!

Altay kudayıbıs tep yaynayırbısta.

Agar baş piyan bolorı kandi?

Ölböy yadarıbıs, surap yadıbıs,

Öçpay adıbıs, surap yadıbıs.

Yaynap yadarıbıs köp boltı.
Altay tanrmizdir, diyerek yalvariyoruz. Bu aylı ve güneşli Ayaz hanımız (Gök):

Ormanll, taşlı Altayımız!
Nüfusumuz çoğalacak mi?

Ölümsiiz hayat diliyoruz,

Çok yalvarlyoruz,

Çok yakarıyoruz (İnan, Şamanizm, S.129)

Orta Asya kavimlerinde güneş ve ay kültü de vardır. Altaylı Türkler ve müslüman Türklerden Mişerler arasında güneşle yemin etme adeti bulunur. Altaylılara göre güneş ana, ay da atadır. Güneşi yerde ateş temsil eder. Bazı Saha masallarında büyük kahramanlar güneş ve ayın himayesi altındadır. Onların inancina göre zaman zaman güneş ve ay kötü ruhlarla mücadeleye girişirler. Eğer yenik düşerlerse güneş ve ay tutulması gerçekleşir. Güneş ve ay tutulması olduğunda Altay Türkleri bağırıp, çağırırlar, davul çalarlar. Bu gürülttülerin kötü ruhları korkutacağma inanılır.

Sahalara göre güneş ve ay iki kardeştir. Her ikisi de üstün özellikleri olan ilahlardır. Oyunun cübbesinde güneşin sembolü olarak demirden ve gümüşten yapılan halkalar vardır.

Yıldızlardan da Çolpan kutludur. Bugün şamanist olduğu söylenen Türklerin yıldırım ve şimşek hakkında da ilginc düşüncelerı mevcuttur. Bunlara göre yıldırım ve şimşeğin hareketleri Ülgen tarafından kontrol edilmektedir. Yıldırım düşen ağaçtan bir parça alıp, saklanırsa, o yere kötü ruhlar giremez. Tuva Türkleri yıldırım ve şimşek çaktığında saçı saçarlar. Çin kaynaklarının Uygurlar hakkında verdikleri bilgilere göre, onlar yıldırım düşmesinden hoşlanırlardı. Gök gürledikçe bağırıp, çağırırlar ve göğe ok atarlardı. Bir yıl sonra yıldırım düşen yerde toplanı, bir koyun keserek oraya gömerlerdi ${ }^{24}$.

İlk insanlar meyve ve otla beslendikleri için ateşe ihtiyaçlan yoktu. Et yemek ihtiyacı ortaya çıktıktan sonra ateş gerek oldu. Ülgen gökten biri ak,

\footnotetext{
${ }^{2}$ İnan, a.g.e., s.49-50.

23 Altay insanı hertaraftan kucaklar ve içine alır. Altay'ın çocukları da ona sevgi ve şükranla cevap verirler. Altay onların kültürlerinin en üst değeridir (Bakınız, Sagalayev, a.g.e., s.61).

${ }^{24}$ Ögel, Türk Mitolojisi, s.140; Inan, a.g.e., s.29-30
} 
biri kara iki tas indirdi. Kuru otlan bu taşlan birbirine sürterek yaktı. Bundan dolayı ateş kutlu olup, Altaylılar ve Sahalar çakmak taşından elde edilen ateşi kutlu saydılar. Altay Türklerinde son zamanlara kadar gelin ve güvey ilk ateşlerinı çakmak taşıyla yakmışlardır. Saha oyunlan da tören için gerekli olan ateşi çakmak taşıyla alevlerler. Kibritle yakılan ateşe Rus ateşi deyip, ayinlerde bunu kullanmazlar. Bununla beraber aile ocağında yanan ateş nasıl olursa olsun kutludur. Altay Türkleri, herşeye küfür etseler de, ateşe hakaret etmezler. Ateşi su ile söndürmek, ateşe tükürmek, ateşle oynamak kesinlikle yasaktır. Ateş gök ile ışıklı dünyanın ve nihayet güneşin bir sembolüdür. Asya Türklerinin çoğu ateşe bakarak fal açarlar. Manas Destanı'nda anlatıldığına göre, Manas'in babası Cakıp Han ateşe bakarak, gelinlerinin mukadderatını söylemiştir. Türklerin itikadına göre ateş herşeyi temizler, kötü ruhları kovar. 6. yüzyılda Kök Türklere gelen Bizans elçilerinin kötü düşüncelerden arındırılmaları için ateşten atlatıldıkları Bizans kaynaklarında kayıtlıdır. Mogollarda da bu adet gôrüulür. Hatta müslüman Türklerde de bu gelenek halâ yaşamaktadır. Başkurt ve Kazak Türkleri bir yağlı paçavrayı tutuşturup, hastanın etrafında "alas, alas" diye dolaştırırlar. Buna "alaslama" denir. Bu kelime Türkiye Türkçesine "alazlama" şeklinde geçmiştir. Manası ateşte temizleme demektir. Bu sebeple eski Türk inancında ateş külttii ile ocak kültui birbirinden ayrilmaz ${ }^{25}$.

Ayas kanıng üleyi, aydın künnüng ülü

Ayaz hanın parçasl, ayın ve güneşin payt

Altın yargı sen sura, al otkongo tabıştır! Altın yargı sen sor, alevli ateşe ulaştır!

Albata biriktir, üzülbeske ülü

Halka ard kesilmeyen kısmet ver

Kaçanda alıp yatsın,

Her zaman ala dursun,

Küngürtçiden ün alıyıp yatsın

Ylldirtm tanrisindan ses alip dursun

Albata piyanın yettirip yatsın

Alır ottıng ezi! Al yalgınıng uluzı

Halka bereket yetiştirip dursun

Ayrilbastm yayagan,

Alevli ateşin sahibi

Astıkpas tın bıçıgan,

Ayrlmaz can yaratmış,

Alır ottu Ak-Yayık! Tengeredegi kuday!

Şaşmaz ruha biçim vermiş

Alevli ateş sahibi Ak Yaylk! Gökte Tanr?!

(İnan, Şamanizm, s.128)

Ölüm halinde yas törenleri düzenlenir, bu sırada acılarını dile getirmek için bağrışarak yüzlerini, gözlerini çizerlerdi ${ }^{26}$. Bundan sonra ölü için yemek

\footnotetext{
${ }^{25}$ İnan, a.g.e., s.66-68.

${ }^{26}$ İbn Fazlan.... s.63. Mesela Orkun yazitlarnda yog adetiyle alakalı olan ibarelere rastlamaktayız. Köl Tigin ve Bilge Kagan yazıtlanında 714 yılında, Beş-Bahık seferi sırasında
} 
verme adeti vardı ki, bu gelenek günümüze kadar gelmiştir. Bütün Türk topluluklarında ölünün hatırasına düzenlenen yok olmaktan gelen "yog" merasimleri tertip edilirdi. Ölen hükümdarlar veya kahramanlar için kabirlerinin başına hayatta iken savaşıp öldürdükleri kişilerin sayısı kadar balballar dikerlerdi. Bu saydiklarımızın hepsi Türklerin semavi dinlere girmeden önceki adetlerinin umumi bir görüntüsüdür. Hatta bunların bazıları Hak dinlere girdikten sonra da, Türklerin dini hayatlarında süregelmişlerdir. Sahalar ölümü, insanın ruhunu kötü ruhların kapıp, yemesi ile açıklar. Ölüm halinde ruhun bir kuş şeklinde uçup, gittiği düşünülür.

Şamanizm hususunda bugüne kadar en ciddi çalışmayı M.Eliade yapmıştır. O, Orta ve Kuzey Asya topluluklarında dini hayatın Kam etrafında yoğunlaştığını söyler. Ancak Kam bütün dini faaliyetlerde rol oynamaz. Her sihirbaz Kam olmadığı gibi, her şifa verici de Kam değildir. O, Samanlığa k1saca "vecd ve istiğrak (extase) tekniği" demektedir. Bununla beraber dinler tarihinde ve din etnolojisinde görülen çesitli vecd hallerinin hepsi de Şamanizme girmemektedir. Eliade'ye göre Kam herşeyden önce kendi özel yöntemleri sayesinde ulaştığı extase hali içinden ruhunu göklere yükselten veya yeraltına indiren bir kişidir. Bu esnada başka ruhları hükmü altına alarak, tabiat güçleri ve şeytanlarla bağlantı kurmaya muvaffak olur. Kam ateş üzerinde hakimiyet kuran, hastalanan ruhlara şifa veren, ölülerin arzularmı yerine getiren, dertlilerin sikayetlerini dinleyen, yer altındaki tannlann yanına giderek aracılık yapabilen bir kişidir. Bu özellikleriyle de çevresinde korkuyla karışık bir saygı uyandırır ${ }^{27}$.

Şamanlıkta ruhun uçuşu (göklere yükselme veya yeraltına inmesi) ile extase aynı anda meydana gelir. Şaman gerek gökte Bay-Ülgen ile gerek karanlıklar dünyasında Erlik gibi tanrılarla dostluk kurar, onları görür ve onlarla konuşur. Hastanın vücudundan çıkmış olan ruhunu bulur ve geri getirir, yani hastalığı iyi eder. Şamanların elbiselerinde her şeklin bir manası olan semboller vardır. O külahlar giyer, maskeler takar. Üzerinde özel tasvirleri bulunan davulunu veya defini çalar ${ }^{28}$. Kendinden geçinceye kadar çeşitli şekillerde zıplar, sıçrar, acaip sesler çıkarır. Bazan da bayılır. Kırgız ve Kazak baksılan Altay ve Saha kamlan gibi özel cübbe ve elbise giymezler. Bunları diğer insanlardan ayıran hususiyetleri, perçem ve külahlarına taktıkları kuş tüylerıdir. Bazı baksılar bunlara da önem vermezler. Sıradan insanlar gibi gezerler. Kazak baksıları Altaylı meslektaşlarından farklı olarak kopuz kullanırlar. Kırgızlar kadın baksılara "bübü" derler ki, Bibi'den bozmadır. Kamin cübbesine Altay Türkleri "manyak", Saha Türkleri de "kumu" veya "oyun tangası" (oyun giyimi) adını verirler. Mesela Kumandılarda kamlar, kurban törenlerinde yalnız beyaz bir cübbeyle, kayın ağacı kabuğundan yapılmış hưni biçiminde bir külah giyerler. Bunun yanısıra kara kamların aksine ak kamların daha basit ve sade giydikleri görülmüştür. Günümüzde kamların, gerçekten otantik giysilerinin neler oldugunu tesbit etmek oldukça zordur. Zaman içerisinde bunlarda büyük değişiklikler olmuştur. Yinede Türkistan'ı ve Orta Asya'yı gezmiş olan seyyahların vermiş olduğu

ölen amcalarnın oğlu Tonga Tigin'in yogundan (mateminden) bahis vardır. Bakınız, S.Gömeç,

"Atsız Bir Kahraman: Tonga Tigin", Türk Kültürü, 33/390, s.63-64.

${ }_{27}$ Radloff, a.g.e., s.233.

Inan, a.g.e., s.90-96; Radloff, a.g.e., s.234-236; Ögel, a.g.e., s.29. 
malumatlar ve eski tarihi kaynaklara bakarak bunların şekli hususunda bir fikir edinmek de mümkündür.

Ayin yapmak için gerekli olan nesnelerin en önemlisi davuldur ${ }^{29}$. Davul belki de kamın giysisinden çok daha eskidir. Tarihi kam giysilerinin izlerinin kalmadığı yerlerde bile davul kendisini korumuştur. Altaylilar ve Sahalar bu davullarına "tüngür" derler. Tüngürle (tünür, tür) birlikte bazan "çalu" da denir ki, araştırmacıların bir kısmı bu tüngürü mogolca asıllı kabul ederken, bir kısmı da çalunun Türkçe çalmak fiilinden türediğini söyler. Davul Türkler tarafından tarihin en eski devirlerinden beri kullanılmaktadır. Buna ait Cin kaynaklarında da kayıtlar mevcuttur. Eski Yenisey Kırgızları ve Oguzlar, tarihçi Gerdizî'nin malumatuna göre kopuz kullanmışlardır. Bu özelliğıyle de kopuz Türklerin milli çalgısı olmuştur. Yani bugünkü bağlamanın veya sazın atası kopuzdur. Bilindiği gibi Dede Korkut her hikayesinde kopuzuyla ortaya çıkmaktadır. Ad verirken, dua (alkış) ederken hep kopuzunu kullanır. Saha oyunları ise davul bulamadıkları zaman at kuyruğundan yararlanırlar.

Karagay kobuz kolga aldım. Çam ağacından kopuzumu elime aldım.

$\mathrm{Ab} 1 \mathrm{cllanday}$ tolgandım.

Bu kopuzum sinmadi,

Garip canım tınmadı.

Onbeşimde cabıstı,

Cirmıda tabistı.

Könbes iske köndürdü,

Kuv agaçka töndürdü

Kök kiyimdi börte atım,

Altı kulaç ala atım.
Suya yılan gibi dolandım.

Bu kopuzum kırtlmadt,

Garip canim rahat durmadl .

Onbeşimde yapıştt,

Yirmi yaşımda buluştu.

Istemediğim işe zorladl,

Kurumuş ă̆aca döndürdü .

Gök giyimli kır atım,

Altı kulaç ala atım (İnan, Şamanizm, s.137).

Davulun kasnağı kayın veya sedir ağacından yapılır. Bu ağaca da daha önce insan ve hayvanın dokunmamış olmasına özen gösterilir. Derisi geyik, dağ keçisi ve taydan olabilir. Davulun üzerinde resimler yerdeki ve gökteki varlıklara aittir. Sağda ay, solda güneş ve bunların arasında yıldızlar; kuş ve geyik resimleri görülebilir. Her kamın davulu ölümünden sonra bir ormana götürülerek, parçalanıp, bir ağacın dalına asılır. Kamı ölüsü de bu ağacın dibine gömülür. Kamlar mümkün olduğu kadar obadan ve yollardan uzak bir tepeye, hayvan sürülerinin yaklaşamayacağı bir yere defnedilirler. Eski inanışlara göre, her kamın evinde iki davul bulunur. Bunlardan biri ayinlerde kullanılır, ikincisi de bir köşede saklanır. Bazı istisnai durumlarda kamlar davul yerine yölgö (küçüik yay) bulundururlar. Fakat yölgö ile tam bir tören

${ }^{x y}$ Bir inanışa göre, kamların en önemli çalgıları olan def veya davul Erlik tarafından icat edilmiştir (Sagalayev, a.g.e., s.31). 
gerçekleştirilemez. Altay Türkleri davul tokma ğına "orbu", Sahalar ise "bulaayah" derler. Bu tokmak kayın ağacından veya sıgun (geyik) boynuzundan yapilır.

Davul tören sırasında, kamın ruhu dünyayı dolaşırken taşıt görevini ifa eder. Karada gezerken davul at, tokmak kamçı; sulardan geçerken davul kayık, tokmak kürek; göklere çıarken kuş vazifesindedir. Doğu Türkistan'ın müslüman bakşıları, davul yerine dap (def) ve dombak kullanırlar. Ayin yaparken def kamın arkadaşı tarafından çalınır, dombakı ise bakşı kendisi çalar. Bazı bakşılar ravab (rübap) denilen ựç telli bir saz ile tören icra ederler.

Bunun yanı-sıra ayna da kamların dini ayinlerinde önemli rol oynar. Aynanın yardımıyla kam veya oyun fala bakar, geleceği söyler, tedavi eder. Ayna hastalıklara sebep olan ruhların görülmesi ve hastalığın sonucunu ögrenmede bir araçtır. Mesela Tacikler de bile çocuğun yastığının altına nazardan, korkudan ve kötü güçlerden sakınmak gayesiyle ayna konulmaktadır ${ }^{30}$.

Eski Türk dininde ayin ve törenlerin iki kısma ayrıldığ 1-Muayyen zamanlarda yapilan ayin ve törenler. 2-Sirf tesadüf olaylar dolayıstyla yapılan özel törenler. Belirli vakitlerdeki törenler ilkbahar, yaz ve güzün yapıllır ki, bunların geçmişi çok eskilere dayanır. Eski Türk sülaleleri bunları dini bayramlar olarak kutluyorlardı.

Bahar bay ramı müslüman Kazak, Kırgız ve Başkurtlarda "kımız murunduk" adıyla günümüzde bile mayıs ayında yapılmaktadır. Başkurt kadınları ilkbaharı erkekleri karıştırmadan, "karga toy" diye kutlarlar. Bu törende kargalara darı, süt konur. Törene küçük erkek çocukları dahi kat1lamaz.

Sonbahar bayramı kötü ruhlardan korunmak için yapılırdı. Bu bayrama abası ısıga (kötü ruhlara saçı) adı verilirdi. Bu isme rağmen törenin ilk gününde aydınlık ruhlardan Ulu Toyon, ikinci günde kötü ruhlarn lideri Arsan Dulay namına ayin gerçekleşirdi ${ }^{31}$.

Türklerin eski inanç sistemine göre aşağı-yukan kurbansız ayin yapılmaz. Kurban mefhumunun da eski Türkçede tam karşıllğ̆ kesin olarak bilinmemektedir. Günümüz Türk boylarında tayllga ve hayllga kelimeleri varsa da, mogolcadan geçtiği düşünülmektedir. Saha Türkçesinde kurban anlamına gelen kereh sözü vardır. Oyunun iştirakıyla ruhlara sunulan kurbana denilir. Kurban edilen atın, sırkklara takılan derisine de bu ad verilir. Eski Türk yazıtlarında da bu kelimeyi görmek mümkündür. Öldü yerine kergek bold $\iota$ veya uçmağa bard $\iota$ deyimleri söz konusudur. Sahaların kereh kelimesi de bundan başka birşey değildir. Bu kelimeye yine kurban manasinda mogolca ve buryatçada da tesadüf edilmektedir.

*o Inan, a.g.e., s.93-96; R.M.Mustafina, Predstavleniya, Kultı, Obryadı u Kazakov, Alma-Ata 1992, s.135.

${ }^{31}$ Inan, a.g.e., s.97-102; Toyon, Saha Türkçesinde "Tanrı" manasına gelmektedir.. 
Kanlı kurbanlardan başka bir de kansız kurbanlar vardır. Saçı, yalma (ağaçlara veya kamın davuluna bağlanan paçavralar), ateşe yağ atma, tözlerin ağızların yağlama ve kımız serpme gibi törenler bu kansız kurbanlardır. Kansız kurbanların en önemlisi ruhlara bağışlanarak başı-boş salıverilen hayvanlardır. Bu tür kurbanlara eski Türkler "ıduk" demişlerdir. Bunun kelime karşılığı "salıverilmiş", "gönderilmişs", "kutlu" demektir. Terim olarak "tanrıya gönderilmiş, tanrıya bağışlanmış hayvan" anlamını tașır. Bu hayvana yük vurulmaz, sütü sağılmaz, yünü kırpılmaz. Kansız kurbanlardan olan saçı ise bütün Türk boylarında müş̧terektir. Bu Türkçe kelime mogolcaya "saçu" şeklinde girmiştir. Saçıya dini terim olarak saçılga veyahut çaçılga da denir. Saçı her boyun kendi emeğiyle kazandığ nimetlerden biri olur. Konar-göçer Türklerde bu süt, kımız, yağ; çiftçi Türklerde de buğday, dan, şarap; tiiccarlarda ise para olabilir. Bu saçı adetini dünyanın başka kavimlerinde de görebiliriz. Birisi hakkında hayırlı haber verilirken "darısı başımıza" temennisi de bu eski töreden gelmektedir. Kök Tengri dininin geleneklerini yaşatan bugünkü bazı Türk boylarıla, müslüman Türklerde evlenme hadisesi sırasında da saçı saçılmaktadır. Burada saçının amacı, yabancı bir soydan gelen gelinin, kocasının ailesi tarafından kabul edilmesi için yapılan gelenektir. Gelinler için birçok şeyler tabu sayılır. Kocasının ve onun soyuna mensup erkeklerin adını söylemek, kayınpederi ve kayınlanıyla konuşmak ayıp karşılanmakta idi. Bu geleneğin son yıllara kadar yaşadığını bizzat ben annemden dinledim.

Her tören için kanlı veya kansız kurban sunulması gerekir. En önemli kurban attır. Attan sonra koyun gelir. Gerek bugün Kök Tengri dinini devam ettiren Türklerde, gerekse müslüman olmuşlarda kurban için en makbul hayvan erkek olanlardır. De de Korkut hikayelerinin kahramanlan Oguz Türkleri kurban olarak "attan aygır, deveden bugra, koyundan koç" kesmişlerdir. Kırgız ve Kazaklarda da aynı motiflere rastlanılır.

Kurban kesilen hayvanların kemikleri kırılmaz. Köpeklere verilmez. Ateşe atılır veya yere gömülür. Bazı özel törenlerden sonra kurban kemikleri toplanarak, bir kaba konulup, kayın ağacına asılır. At kurbanlarının kafatası ise bir sirk üzerine konulur. Altay Türkleri ve Sahalar kurban olarak kestikleri atın derisini bir sırığa geçirip, tıpkı at şekline sokarlar. Buna Altay Türkleri baydara, Saha Türkleri tabık derler.

Kamların diğer insanlar üzerinde tesirler bırakan bu hareketlerinde başarılı olmasının bazı şartları bulunmaktadır. Bu şartlar, Kam olma konusunda kendini gösterir. Buna göre Kam olmak için ya bir kam ailesinden gelinmeli veya doğrudan doğruya kendi yeteneklerine göre halk tarafından seçilmelidir. Kamlik sanatı ögrenilmekle elde edilemez. Kamlar bağlı olduklan toplulukların gelenek ve göreneklerini iyi bilmelidir ki, ona göre tedavilerde bulunabilsinler. Bunun için genç kamın mutlaka yaşlı ve tecrübeli bir kam tarafından yetiştirilmesi lazımdır ${ }^{2}$. Sahalarda oyun namzedi mesleğe girmeğe hazırlanırken mensup olduğu oymak toplanıp bir dağa veya tepeye çıar. Namzedin üzerine kumu giydirirler, eline at kılları bağlanmış bir asa tuttururlar. Adayın sa $\breve{g}$ tarafinda dokuz delikanlı, sol tarafinda dokuz kız, bunların ortasında da bir ihtiyar oyun yer alır. Yaşlı oyun mesleğe sadakat yemini olan duayı okur ve aday da bunu tekrarlar. Kamlar seleflerinin

${ }^{32}$ Radloff, a.g.e., s.233 
okudukları duaları ezberlemek zorunda değildir. Çünkü kamların ayin ve vecd halindeyken söylediklerini tesbit etmek de çok zordur. Törenden sonra kendisi de söylediklerini tekrarlayamaz. Kamlar bir sürü ruhlara sahiptirler. Bunların bir kıs mı kamı korurken, bir kısmı da ona yardım etmekle vazifelidir. Bu ruhların hepsinin kişisel isimleri, özel bir şarkısı ve kendine özgü simgeleri vardır $^{33}$. Bu ruhlar büyük çoğunlukla hayvan biçimindedirler. Sibirya kavimlerinde bunlar ayı, kurt, geyik, tavşan ve çeşitli kuşlar, özellikle kartal, baykuş ve karga şeklinde görülebilirler. Mesela yeraltına inerken yanında "ayı perisi", gökyüzüne çıkarken "at ruhu"ndan yardım görür. İhtiyaç halinde o dünyanın her tarafından yardımcı ruhlar çağırır. Bu daveti davulunu veya defini çalarak yapar. Yardımcılarının geldiklerini onların seslerini çıkararak belirtir. Tunguz şamanının baş yardımcısı yılan sesini, Eskimo şamanı kurtu, Japon şamanı ren geyiğini taklit eder. Şamanların bu hayvanların gizli dillerini de ögrendikleri söylenmektedir ${ }^{34}$.

Ak adamnang tögölüp yat.

Ala sungkur er aldıma akşıgay

Poro mürküt ekki iynime singıgay

Yezim taygadan sungan Çuyuk
Ak atamdan dökülmektedir.

Ala sungur tam önümde bagtrtr.

Boz kartal iki omuzumda bağırsin.

Yezim (dă̆ından) uzanan (Kam) Çuyuk (Înan,

Şamanizm, s.129).

Davulunu çalarak cinleri ve perileri toplayan oyunun elindeki ip veya asa bir kozmik bölgeyi diğerine bağlayan yoldur ${ }^{35}$. Esasen kamın mistik seyahatlarında kullandığı baska araçlar da vardır. Mesela kayın ağacından yaptığı dokuz basamaklı merdiven, gök kuşağı gibi.

Genellikle gerçek kamlar dünya malına düşkün değildirler. Onlar hakkunda söylenen menkıbelere göre fakir insandırlar. Kamların kendileri de böyle yaşamaya inanmışlardır. Onlar birer hokkabaz olmadıklarını törenler sırasında ekstaz halleriyle gösterirler. Bunu başaramayanlara şarlatan gözuiyle bakarlar. Bazzı kamlar aynı zamanda kabile veya oymağın öğütçüsü görevini de yüklenir. Ögüut vermek kamın tekamülünü gösterir. Hayatı boyunca kamlar cinsi münasebetten uzak, günahtan arınmış, oruç tutmaya ve susuz kalmaya dayalı bir yaşam tarzını sürdürmek zorundadırlar ${ }^{38}$. Kamlar gerek erkek, gerek kadın olsun bir kast halinde bulunmazlar. Mensup oldukları boy, oymak veya köyün bir üyesi olarak halk içinde yaşarlar. Onların diğer insanlardan üstünlüğü ancak ayin sırasındadır. Ekstaz hali geçtikten sonra diğer ölümlülerden hiçbir farklan kalmaz.

Her kamın kendisinin özel ruhları olduğunu söyledik. Altaylı kamlar bu özel ruha "tös" (töz), Sahalar "iyekil" derler. Töz külttüyle, mogolca ongon

${ }^{33}$ S.Kan, "Shamanism and Christianity: Modern Day Tlingit Elders Look at the Past",

Ethnohistory, 38/4, Durham 1991, s.365.

${ }^{\sharp}$ Kafesoğlu, a.g.e., s.31-32; Tanyu, a.g.m., s.204

${ }^{35}$ Buluç, a.g.m., s.315

${ }^{36}$ Kan, a.g.m., s.365. 
kültünün alâkası mevcuttur. Töz, bugünkü Türk lehçelerinde asıl, kök, menşe demektir $^{37}$. Eski Türklerin ve bugünkui Altay Türklerinin bu heykelciklere tờz adını vermeleri, bunların ataların hatırası için yapıldı̆̆ ını göstermektedir. Gerçekte böyledir. Altaylılar bunlar hakkında "bu babamın tözü, bu anamın tözü"' derler. Büyüik ve ünlü kamlann hatırasına yapılmıs tözler de vardır. Mogolların ongon külttüyle ilgili araştırmalar yapan D.Banzarov bu kültün ölii kültüyle ilgisi olduğunu söylemektedir. 1253 senesinde Fransa kralı IX. Ludwig tarafindan Mogolistan'a Mengü Han'n huzuruna elçi olarak gönderilen Rubruk'un bir budist Uygur tapınağında gördügüü putlar hakkındaki malûmatından, bu tözlerin aslı hususunda bir netice çkarmak mümkündür. Rubruk; "Uygurlar bir Tanriya inanırlar. Tanrının insan veya başka bir cisim halinde tasvir edilmesini kabul etmezler. Onlara niçin bu kadar putunuz var diye sorduğumda, bizimkilerden birinin herhangi bir yakını öldüğü zaman, onun suretini yapar ve buraya koyar. Biz de bunları ölünün hatırası olarak saklarız" demektedir ${ }^{38}$.

Ebu'l-gazi Bahadır Han da tözler hususunda açıklamalar yapmaktadır. Onun anlatığına göre; "bir kişinin oğlu, kızı veya kıymetli bir yakını öldüğü zaman suretini (kugurçak) yapar, evinde saklard1. Ara-sıra bu heykelciği öpüp, severlerdi. Bu suretin önüne yemeklerinin ilk lokmalarını korlardı. Onları okşayarak, koklarlardı. İşte böylece haberleri olmaksızın puta tapmaya başladılar", diyor. Ebu'l-gazi'nin kugurçak dediği nesne, bebek (oyuncak) demektir. Altaylıların tözlerinin büyük çogunluğu da bebeklerden ibarettir.

Ongon kelimesini Çagataylılar, mogolcadan alarak damga, ayırıcı belge anlamında kullandılar. Reşideddin vasitasıyla bu kelime Osmanlı Türkçesine de geçti. Ongon kelimesini Mogollar, Türkçedeki ıduk yerine de söylerler. Mogollar töz ile ıduku ayırmazlar.

Müslüman Türklerde de eski töz ve ongon kültünün izlerine rastlanılır. Doğu Türkistanlı bakşılar hastaları tedavi ederken birçok kugurçakdan (kukla) faydalanırlar. Başkurt ve Tobol bakşıları sıtma hastalığını paçavradan yaptıkları korçaklara (kukla) nakledip, uzaklara götürürler.

Özellikle Türklerde ve Mogollarda ongon olarak kuşlar tercih edilmiştir. Kuş gibi tasvir edilen ruhlar daha çok Sahalarla, Dolganlarda bulunur. Mesela, ilkbahar ve güz mevsimleri kartalın temsil ettiği ruhun iradesine bağlıdır. Kartal bir defa kanatlarını sallarsa buzlar erimeğe başlar, ikinci defa sallarsa bahar gelir. Reşidedin' in naklettiği Oguz-name'ye göre Irkıl-Hoca Oguz boylarından herbirine bir kuşu ongon olarak seçmiş̧ir. Orta Asya Türklerince meşhur olan Çingiz-name'de de, Çingiz Han, on iki Türk boyuna, nişan olarak birer kuş, damga ve uran (savaş parolası) ve ağaç tayin etmişti ${ }^{39}$.

${ }^{37}$ B.Ögel, Töz sözüyle Türkler, hangi hayvandan veya hangi kuştan türemiş olduklarını ifade ederler, demektedir. Bakınız, Ögel, a.g.e., s.32.

${ }^{\sharp}$ Fransa kralının elçisi Rubruk hatıratında şöyle diyor: "Evin reisinin başının üzerinde duvarda keçeden bir figür bulunur. Bu figür bir bebeğe veya bir heykele benzer ve efendinin kardeşi yerine geçer". Bakınız, W.Rubruk, Moğolların Büyük Hanına Seyahat (12531255), C.ev. E.Ayan, Istanbul 2001, s.34.

* Inan, a.g.e., s.42-47. Mesela son zamanlarda Saha oyunları en kötü hayvanlar olarak kurt ve köpeği görmüşlerdir. En kutlu ise kartaldır. Oyle anlaşıllyor ki, Türk topiuluklarının 
Eski Türk dininin izlerini taşıyan bir de efsun olayı vardır ki, Türkçede buna arvaç veya arbag denir. Yılan ve akrep gibi zararlı böcekler tarafından ısırılanlar olursa müslüman Türkler bu efsuncuları çağırarak, okuturlar. Türk folklor bakiyelerinden öğrendiğimize göre öyle arbagçılar vardır ki, ısıran haşaratı kendi yanına kadar cekebilirlermiş. Bazı haşaratlar ve yılanlar bu arbagçının yanına gelerek, ölürler. Bu efsuncular bakşı, kam ya da oyun değildirler. Ocaklı olan her adam efsun öğrenmişse okuyabilir. Arbagçilar, efsunla birlikte faydalı otlan kullanmayı da unutmazlar. Bugünkü Kazak Türklerinin inancına göre arbaglar veya efsunlar ölen ataların, peygamberlerin, önemli insanların ruhlarının koruyucularıdır. İnsanları tehlikelerden korurlar, iyi düşüncelere sevkederler ${ }^{40}$.

Nur yılan, temir yılan, at yılan, su yılan

Ok yılan, gömülgen yılan, kelte (kısa) marı,

Aydurharı çöl kesen yılan

Hindustani, kara yılan, kör marı, erkek yılan

Urkoçı (dişi) yılan,

Bogoz (gebe) yılan, kısır yılan

Hökm-i Davud, hökm-i Süleyman ilçi geldi.

Küsvend (koyun) geldi, brev, reberev kûf çı!! (Türkmenlerde Yılan Efsunu, İnan,

Şamanizm, s.146).

Eski Türk dininin geleneklerinden birisi de falcılıktır. Fal eski Türkçede trk kelimesiyle ifade edilmiştir. Kaşgarlı Mahmud bu kelimeyi "falcıllı, kahinlik ve yürektekini dışarı çıarmak" diye açıklamaktadır ${ }^{41}$. Türkiye'nin birçok yerinde "irk bakmak" deyimi de, fala bakmak demektir. Oguz destanında geçen Irkıl Hoca'nın adı da bu "ırk"tan geliyor olmalıdır. Sahaların ilk oyununun ismi Argıl'dır ki, bu kelimeyle alakalıdır. Bu şahısların da gelecekten haber verdikleri şüphesizdir. Altaylıların inancında kamdan sonra "rnmcılar" gelir. Bunlanın saralan tuttuğunda gelecekten haber verirlermiş. Kamlar arasında fal anlamina kullanılan başka bir kelime de tölgedir. Ünlï Kırgız destanının baş şahsiyeti Manas'ın arkadaşı Kara-Tölek adlı bir tölgeçidir. Bugünkü Asya Türkleri ve müslüman Türkler de dahil olmak üzere en meşhur fal bakma usulü kürek kemiğiyledir. Etnografya araştırmaları bu tür fala bakmanın aşağı-yukarı biituin dünya milletlerinde old uğunu göstermektedir. Örnek olarak büyük Türk hükümdan Attila, 452 senesinde Romalılarla savaştan önce bu tür bir fala baktırmıs ve savaşın başlamasını da falın sonucuna göre belirlemişti. Kürek kemiği falı Mogol saraylarında çok önemliydi. Rubruk'un verdiği malumata göre, Mengü Han bir işe girişmeden evvel kürek kemiği falı açtırırdı. Bunun için önce kemik ateşte kızdırılır, sonra

medeni seviyeleri yükseldikçe daha ziyade avcı kuşlara doğru meyletmişlerdir (Bakınız, Ögel, a.g.e., s.47).

Inan, a.g.e., s.145-146; Mustafina, a.g.e., s128.

"Divanü Lûgat-it-Türk Dizini, s.218. 
bunun üzerinde meydana gelen çizgilere bakılarak yorum yapılırdı. Mesela Mengü Kagan, kemiğin üzerindẻki çizgiler düz ise sefere çıkar, değil ise çıkmazdı ${ }^{22}$. Konar-göçer Türkler aşık kemiğiyle de fal açarlar.

Türk boylarında eski devirlerden beri yaşayan yaygın bir inanç da, Türk Tengrisi'nin Türklerin büyük atasına yada denilen sihirli bir taş armağan etmesidir $^{43}$. Bu taş ile istendiği zaman yağmur, kar, dolu yağdın̆lır, fırtına çıkartılır. Bu taş her devirde Türk kamlarının ve Türk komutanlarını elinde bulunmuştur. Altay ve Saha Türklerinin inancına göre günümüzde de bu taş büyük kamların ve yadacıların elindedir. Türk lehçelerinde çeşitli şekillerde adlandırılır (sata, cada, cay vs.). İslam kaynaklarında Türklerin bu sihirli taşına "yağmur taşı" ve "cada taşı" denilmektedir. Saha Türklerine göre bu taş at, inek, ayı, kurt gibi hayvanların içinde bulunur. En kuvvetli yada (sata) taşı kurdun karnından çıkarılandır. Onların itikadına göre bu taş canlıdır. Insan kafasına benzer. Yüzü, gözü, kulağı, ağzı çok açık bellidir. Kadın veya bir yabancının eli veya gözü dokunursa ölür, kuvvetini yitirir. Canlı yada taşı yukarı doğru kaldırılırsa derhal soğuk bir rüzgar eser, yağmur veya kar yağar ${ }^{44}$. Türkiye'nin bazı bölgelerinde yağmur yağdırmak için taş okuyup suya atmak adeti, bu yada taşı ile irtibatlıdır.

${ }^{42}$ J.M.Deguignes, Hunların, Türklerin, Moğolların ve daha sair Tatarların Tarih-î Umumisi, C. II, İstanbul 1924, s.174-175; İnan, a.g.e., s.151-152. W.Rubruk hatıralarında şöyle diyor: “Biz tam Mengü Han'ın çadırına girdiğimizde elinde kömür karası gibi yanmış bir kemik taşıyan hizmetçiyle karşılaştık, sonradan öğrendim ki Mengü, kemik falına bakmadan dünyada hiçbir işe girişmezmiş. Birşeyler yapmayı planladımı üç tane yanmamaş kemik getirtir. Çadırının yanında bu kemikleri yakmak için iki küçük yurt daha vardır. Bunlar bütün hizmetkarlar tarafından günlük olarak kontrol edilir. Kendisi bizzat, kemiklerin ateşin ısısıyla bir süre sonra gerçekten mi yarılmış olduklarını tedkik eder. Böyle ise ona yol açıktır. Eğer kemikler enine patlamış ve yuvarlak kıymıklar halinde parçalanmışlarsa hiçbir işe teşebbüs etmez. Bakınız, Rubruk, a.g.e., s.94.

${ }^{43} \mathrm{Bu}$ taşın üzerinde "Tann”" adının yazılı olduğu, bunun bütün Türklerce bilindiği kaynaklarda zikredilir. Efsanelere göre, "Türk" ile amcazadesi "Oguz" arasında Yada Taşı meselesi yüzünden çıkan anlaşmazlık sırasında Türk'e Çin'den on kam, yani batıdaki On Ok kabilelerinin ilim sahibi olan cedleri geldikten sonra, hakimiyet Türk'üin eline geçmiştir. Bakınız, Deguignes, a.g.e., C. I, s.164; Gömę̧, a.g.t., s.223; V.Minorsky, "Tamim Ibn Bahr's Journey to the Uyghurs", Bulletin of the School of Oriental and African Studies, XII, Bruxelles 1948, s.285.

${ }^{44}$ Inan, a.g.e., s.161-163. Hicretin 21. yllında Ömer'in valilerinden Abdurrahman bin Rabia'nın bir savaşta Türkler tarafından öldürülmesinden sonra yapılan cenaze merasimini fırsat bilen Türklerin yağmur duası yaptıkları zikrediliyor. Yağmur yağdırma geleneğine Kazak Türkleri "Tasattık" demektedirler. Başkurtlarda; Belorezk bölgesinde Taş Kolon veya Yay Taşı denilen taştan bir tay heykeli bulu nmaktadır. Taş Kolon önceleri kutsal bir taş sayılırdı ve İnzer, Katay, Tamyan, Kumınk boylarından olan Başkurtların ibadet yeri olarak kullanılırdı. Bununla yağmur yağdınldı̆̆ına veya yağan yağmurun durdurulduğuna inanılırdı. zerbaycan bölgesindeki Kuşar'a băğı Gil Köyü'nde Sindivir Deresi'nin kenarında bulunan ve yaklaşık $70 \mathrm{~kg}$ kadar olan büyük bir taş kuraklığın şiddetli olduğu zaman akarsu içine atılırken bugün bu gelenek tamamen bırakılmıştır. Bakınız, Taberi, Milletler ve Hükümdarlar Tarihi, C. 4, Çev. Z.K.Ugan-A.Temir, İstanbul 1958, s.254; M.M.Sagitov, "Başkurt Folklorunda Hayvanlara Tapınma", Türk Dili Araştırmaları Yıllığı (Belleten), 1982-83, Ankara 1986, s.127; N.Gözaydın,"Dağıstan, İran Ve Türkiye'de Yağmur Duasındaki Bazı Ortak Motifler Üzerine", III. Milletlerarası Türk Folklor Kongresi Bildirileri, IV. Cilt, Gelenek, Görenek ve İnançlar, Ankara 1987, s.166. 
Çömçe gelin ne ister, Çömçe gelin su ister

Ver, Allahım ver! Yağmur ile sel!

Koç koy un kurban, göbekli harman,

Yaz yağmuru yalancı, gavur kızı dilenci

Ver, Allahım ver! Yağmur ile sel!

Koç koyun kurban, göbekli harman! (İnan, Şamanizm, s.165).

Kayrakan, Kayrakan!

Alas, alas, alas!

Alakança açık per,

Temeneçe teşik per!

Uktu kişi ürönimin

Urlı angış tazılı

Abu Tobı kiygırgan

Ongostoy Kaldırak kıygırgan

Tengerening kindigi yerde!
Kayrakan, Kayrakan!

Alas, alas, alas!

Avuç içi kadar açık ver,

Çuvaldı kadar deşik ver!

Asil kişinin torunuyum

Sedir ağacmm köküyüm.

Abu Tobı diyerek çă̆ırdım

Ongostoy Kaldırak diye çă̆ırdım

Tanrinin gönbeği yerde (Altaylarda yağmurun kesilmesi için yapılan dua. Inan, Şamanizm, s.163).

Görülüyor ki, bugünkü Türk inancı bir dinden ziyade, temel prensibi ruhlara, cinlere, perilere emir ve kumanda etmek, gelecekten haber vermek düşüncesi olan bir sihirdir. Bütün bu anlatılanlar sadece Asyalı Türk topluluklarına ait değildir. Ufak tefek değişiklikleri olmakla beraber Şamanizm denilen bu yaşayı Mogollarda, Japonlarda, Eskimolarda, Malezya'da, Avustralya'da, Kafkaslarda, İzlanda ve Kuzey Amerika'da ve Afrika'nın birçok yerinde görülür.

Tarihin dini inançları ve telakkileri değişikliklere uğratarak bazan zenginleştirip, bazan da fakirleştirerek akıp gittiğini söyleyen araştıramacılar her dinin içerisinde şamanik unsurlarm bulunduğunu söylemektedirler. Ve yine araştırmacılar Şamanlığın Orta ve Kuzey Asya topluluklarının gerçek itikatlan olmadığını da iddia etmişlerdir. Buna göre Samanizmin özünde asabi hastalıklar yatmaktadır. Kuzey kutbuna yakın bölgelerde şiddetli soğukların, uzun gecelerin, yalnızlığın ve vitaminsizliğin insanların sinir sisteminde tahribata yol açtı̆̆ 1 bilinmektedir. Kamların sar'a nöbetine maruz kalmaları buna bağlanmaktadır ${ }^{45}$. Ancak bunlar hakiki hastalardan farklı olarak kendi arzulariyla bu duruma gelmektedirler. Çünkü kamlar kendileri hasta olmaktan ziyade, hastalan iyileştiren kişilerdir. Bu yüzden sağlıklı olmak zorundadırlar. Hatta toplum içinde en akıllı kişilerdir de diyebiliriz. Bütün bu olumsuz

${ }^{45}$ Yani güneyden gelen halkların buralara uyum sağlayamayarak bir mücadeleye girmeleri, ruhsal çöküntü içerisinde iken isteriye benzeyen tepkilerle kendilerini kurtardıklan vurgulanmaktadır. 
şartlarda ortaya çıkan kam aciz durumdaki halkı, ruhlarla temasa geçerek rahatlatırlar. Ayin sırasında kamın ağzından çıkan teselli edici sözlerle avunurlar. Genel olarak özetleyecek olursak kamların veya oyunların belli başlı görevleri şunlardır. Bir yıl kadar evden ayrılmayan ölünün ruhunu öbür dünyaya yollamak; av ve savaşlarda talihi döndürmek; hastalıkları iyileştirmek. Onlar şifahi destan edebiyatının da koruyucularıdırlar. Buryatlarda olduğu gibi, Saha oyununun söz hazinesi 12 bin kelimeyi bulduğu halde, halkın konuştuğu kelime sayısı 4 bini geçmez. Kazak ve Kırgızlarda baksılar şarkıcı, şair; müzisyen, kahin, hekim ve halk menkıbelerinin yaşatıcılarıdırlar ${ }^{46}$.

Daha öncede belirttiğimiz gibi Şamanlığın izlerine güney yarım küre ülkelerinde de rastlanmış ve bundan dolayı menşeini sıcak bölgelerde arayanlar da olmuştur. Bưnların başında M.Eliade gelmektedir. Mesela, bazı Orta Asya topluluklarında Ak-Kam, Kara-Kam ayırımının İran tesirli olduğu düşünülmektedir. Altaylılar Ak-Kam, Kara-kam; Sahalar Ayı-Oyun (iyi oyun), Abası-Oyun (şeytani oyun) şeklinde adlandırmalar yaparlar. AkKamlar, cübbe veya külah taşımazlar, davul kullanmazlar. Kötü ruhlar ve karanlık dünyaya ayin yapmazlar, kanlı kurbanlar vermekten sakınırlar. KaraKamlardan ayrı olarak, gündüzleri iyilik ruhlan şerefine ayin ve tören icra ederler. Ayin yaptırmak için halk daha çok kara-kamlara müracaat ederler. Bunun sebebi de aydınlık dünyasının ruhlarının insanlara daha az zarar vermelerine inanış olsa gerek.

Saha Türklerinin bereket ve doğum tanrıçası Ayzıt'ın durumu, dokuz erkek ve dokuz kuz evlatlı Bay-Ülgen'in hali toprağa bağlı kültürlerin tasavvurlarıdır denilmektedir. Örneğin, kamın aynasının da güney kökenli olduğu, davulunun Budizm yoluyla Hindistan'dan geldiği iddia edilmektedir ${ }^{47}$. Şimdi toparlayacak olursak:

Kamlık bir din değildir. Saha Türklerinin birçok tören ve adetlerinde oyuna iş düşmez. Ancak bugün Şamanizm olarak bilinen itikad ve gelenekler Sibirya kavimlerinin sosyal bünyelerine o derece tesir etmiştir k1, bunları söküp atmak çok zordur. Saha Yeri'nde Oyunizm bir inançtan ziyade bir meslek durumuna gelmiştir. Saha Türklerinin hayatında Kök Tengri dini çok önemli bir rol oynamış, bugüunde Şamanizm olarak adlandırilan bu merasimler oynamaya devam etmektedir. Saha bilim adamlarına göre, bugün onların dini inanışlannda büyük tesiri olan Kut-Sür geleneği de, eski Türk dininin felsefi, sanat ve tıbbi yönlerini göstermektedir. Hastalara bakmağa ve tedavi etmeğe çağırılan Saha oyunu, eve girdiği zaman tör yerine, yani baş köşeye kurulup oturur. Boz at derisinden yapılan post üzerine bağdas kurar. Çünkü Sahalarda boz at derisi kutlu sayılan nesnelerdendir. Oyuna akşama kadar birçok çeşit yiyecek ikram edilir. Saha Türkleri için önemli bir özel ayin de ev yapmak içın seçilen yerde yapılan törendir. Sahalar yeni ev kurmak için kutlu bir arsa arar. $\mathrm{Bu}$ törene de oyun karışır.

${ }^{40}$ Kafesoğlu, a.g.e., 35-37; Buluç, a.g.m., s.321; Tanyu, a.g.m., s.204. Kamlar çocuğu olmayanlara da yardımcı olurlar. Mesela Hakaslarda çocı̆̆u olmayanların kamlanması için đin adamı (veya kam) Umay Dağı'na gider. Hakaslar arasında "ana koynu" manasına gelen Umay, ana simgesidir. Kam, dağda çocukların ruhlarının asılı bulunduğu beşikleri alır ve eve götürür. Daha sonra anne olacak kişinin organizmasına yerleştirir (Bakınız, Sagalayev, a.g .e., s.70)

${ }^{47}$ Buluç, a.g.m., s.322. 
Saha Oyunizmine ait ilk bilgilerin 13. yüzyıldan kalma olduğu söylenmektedir. Rus işgalinden sonra, süratli bir şekilde Hrıstiyanlik propagandası yapılmasına rağmen, eski Türk dininin izlerini silememişlerdir. Oyunizm Sovyet dönemiyle birlikte Savaşçı Ateizm ile büyük bir mücadeleye de girişmişti.

\section{c-Kök Tengri İnancı}

Eski Türkler tabiatta bazı gizli kuvvetlerin varlığına inanmışlardır. Bunlar kutsal (yani 1duk) idiler. Tabiat güçlerine itikad, hemen hemen bütün halk dinlerinde mevcuttur. Fiziki çevrede bulunan dağg, deniz, 1rmak, ateş, fırtına, gök gürültüsü, ay, güneş, yıldızlar gibi tabiat şekillerine ve hadiselerine karşı hayret ve korkuyla karışlk bir saygı hissi eskiden beri olmuştur ${ }^{48}$. Mesela ziraatçı kavimlerde daha çok bereket tanrılan olarak bazı kuvvetler bulunur. Şavaşçı kavimlerde ise, zafer tannlan birinci plandadır. Çoban topluluklarda hayvanların yavrulaması veya koyun kırkma zamanlarında özel törenler düzenlenirdi. İşte halk dinlerinin mahalli özelliklerine karşıllk, yüksek dinlerde bütün cihana şamil olan hususiyetler vardir.

Eski Türklerde ruhların insan biçiminde tasavvurları olmadığından putları da olmamıştır. Fakat ruhlara karşı bir saygı bulunduğundan, kahinlik ve falcılık gibi mesleklere Türkler arasında da tesadüf edilmektedir. Avrupa Hunlarındaki falcılığı Latin kaynakları kaydetmiştir. Ayrıca orijinal Kök Türk harfleriyle yazılı Irk-Bitig ${ }^{49}$ adlı fal kitabı ilgi çekicidir. Ancak falcılık ve kahinlik eski ve orta çağ kavimlerinin hepsinde mevcuttur.

Türklerin dini diyebileceğimiz, ancak şimdiye kadar bu dinin ismi hakkında bir belgeye rastlamadığımız, fakat kitabelerden yola çıarak Kök Tengri dini olarak adlandırabileceğimiz bu inancın temelinde ölmüs atalara saygı, onlar için kurbanlar kesilmesi (ki bu babaerkil toplumlara mahsustur), baba hakimiyetinin ailedeki belirtisi olarak sayılmaktadır. Bu itikata göre insanların ruhu öldükten sonra bile yaşamaktadır. Din tarihi araştırıcıları ve etnologların Türk halkları üzerine yapmış oldukları incelemeler, Kuzey Asya ve eski Orta Asya kavimlerinde Atalar Kültü'nün bulunabileceğini ortaya koymuştur. Asya Hunlan her yılın mayıs ayı ortalarında "Kutlu Atalar Mezarlığı"nda kurban keserlerdi ${ }^{50}$. Türklerde atalara olan saygı, onların mezarlarına yapılan hakaretlerin şiddetli bir şekilde cezalandırılmaları şeklinde de görülür. Mesela Attila'nın Balkan seferi (442), Hun hükümdarlarına ait mezarların, hrıstiyan papazlar tarafından soyulması yüzündendir ${ }^{51}$. Türkler için büyük hakaret olan bu davranışa hrıstiyan hırsızları, Türk mezarlarına ölülerin değerli eşyalanyla gömülmeleri sevketmiştir. Çünkü Türkler öbür dünyaya, yani ölümden sonra ikinci bir hayatın varlığına inanıyorlardı. Bunun

4* Y.Çavuşoğlu, "Eski Türk Dini”, Tanıtım, 7/79, İstanbul 1986, s.30.

4) Irk-Bitig için bakınız, H.N.Orkun, Eski Türk Yazıtları, C. 2, İ̀tanbul 1938, s.7193; S.E.Malov, Pamyatniki Drevnetyurkskoy Pismennosti, Moskova-Leningrad 1951, s.80-92; V.Thomsen, "Dr.M.A.Stein's Manuscripts in Turkish Runic Script from Miran and Tun-huang", Journal of Royal Asiatic Studies, London 1912, s.196-210; S.G.Clauson, "Notes on the Irk Bitig", Ural-Altaische Jahrbuicher, Vol. 33, Wiesbaden 1961, s.218225. s.330-331.

${ }^{50}$ Gömeç, a.g.t., s.l19.

"İ.Kafesoğlu, Türk Milli Kültürü, 2. baskı, İstanbul 1983, s.75; Buluç, a.g.m., 
gibi İbn Fadlan'ın verdiği bilgilere göre, Hazarlar ve Oguzlar, mezarlarının bulunmaması için ölïyü urmak yataklarına gömdükleri vakidir. Onlar ilk önce ırmağın yatağını değıştiriyorlar, sonra buraya bir mezar inşa ederek, suyu tekrar eski yatağına akıtıyorlardı.

Eski Türkçede "ruh, can" manasına gelen Tin kelimesi kullanılıyordu. Bu aynı zamanda "nefes" demekti. Ölümü nefesin kesilmesi, ruhun bedenden çıkıp uçması şeklinde tasavvur ediyorlar, bazan ölü yerine "uçmak" tabirini kullanıyorlardı. Mesela son zamanlara kadar Kazakistan'ın Sır-derya ve Turgay bölgelerinde ölen erkeğin mezarının üstüne en sevdiği atının kafatası mızrak veya bir sırık üzerine saplanıyordu. Ölen için yerine getirilmesi lazım olan adetler bir yıl içerisinde tamamlandıktan sonra, mızrağı kırıyorlardı. Parçalar mezarın üzerine saplanıyordu. Böylece mızrağın parçalarından ölenin ruhu göklere uçuyordu ${ }^{52}$. Bugüne kadar kitabeler üzerine yapmış olduğumuz incelemelerde, altı yazıtta biz uçmak terimine tesadüf ettik. Uçmak'1 Türkler aynı zamanda cennet için de kullanmışlardır. Bazan Türklerin evlerinde atalarının suretlerini tasvir eden töslere rastlanılmıstır. Mesela daha öncede belirttiğimiz gibi, 13. yüzyılın ikinci yarısında Mogolistan'a giden elçi Rubruk, bir Uygur mabedinde puta benzeyen bazı nesneler görmüşs ve putlar nedir diye sormuştur. Uygurlar da bunlar tanrı tasvirleri değil, içimizden biri öldüğii zaman yakınlan onun suretini yapar ve tapınaklara koyar, biz de bunları ölünün hatırası olarak saklarız, diye cevap vermiştir. Yani bu durumun ne totemcilikle, ne de kamlıkla bir alakası yoktur. Ancak bu husus bazı diğer kavimlerde ölen kudretli insanların sonradan ilahlaştırılıp, yarı tanrı durumuna sokulacak kadar ileri götürülmüştür. Ölünün daha mutlu yaşayacağına inanılan bazı Hind-Avrupa kavimlerinde ölünün mezarnna eşyalan konur, hatta önemli ölülerin akrabalan da öldürülerek yanına gömülürdü. Kuzey Avrupa topluluklarının kutsal hayvanları domuz için yaptikları törenlerde insan kurban ettikleri bilinmektedir. Insan kurbanı esasen Sami kavimlerinde ehemmiyet taşıordu. Arabistan' In kuzey bölgesinde bereket ile ilgili olarak, tabiatı idare eden tannılara insanlar kurban edilirdi. Tanrının hiddetini yatıştırmak için cahiliye devri Araplarınca en kıymetli evlat olan erkek çocuk takdim olunurdu. $\mathrm{Hz}$. Isa'nın insanlığ 1 kurtarmak için kendisini feda ettiği telakkisi gibi, İslamiyette kutlanan Kurban Bayramı, Hz. İbrahim'in oğlu İsmail'i kurban etme hikayesidir.

Eski Türklerde en büyük kurban, bozkırlı Türk'ün ençok kıymet verdiği hayvan at idi. Orta Asya'nın Türk bölgelerinde, özellikle Altaylardaki kurganlarda, birçok at iskeleti bulunmuștur. Hatta çok enteresandır ki, bugünkü Kazak ve Kırgızların bazılarını Kurban Bayramında dahi at kurban ettikleri söylenmektedir. Insan kurbanı bozkır külttürünün değil, ziraat külttürünün belirtisidir. Bu mühim noktayı dikkate alan tanınmış kültür tarihçisi W.Eberhard, Türklerde böyle bir adetin mevcut bulunmadığını ve hatta Türkler kendi hakimiyeti altında bulunan bazı kavimlere bunu yasak etmiştir, demektedir ${ }^{53}$.

Türklerin eski inancı Kök Tengri itikadı idi. Kök Tengri bozkır kavimleri inancında tek yaratıcı olarak görünmekte ve din sisteminin merkezinde yer

\footnotetext{
\$2 Mustafina, a.g.e., s.97.

${ }_{53}$ W.Eberhard, "Eski Çin Kültürü ve Türkler". DTCF. Dergisi, 1/4, Ankara 1943 , s.21.
} 
almıs bulunmaktadır. Bütün Türk boylarında kurban sunulan en yüksek kutsal varlık Kök Tengri olmustur. Tann tam iktidar sahibidir. Aynı zamanda semavi mahiyeti olduğu için Kök Tengri adı ile zikredilmiştir ${ }^{54}$. Illim adamları Kök Tengri inancını doğrudan doğruya bütün Türklerin ana kültü olarak vasıflandırmıştır.

Kök Tengri itikadının esaslarını aşağı-yukarı Orkun kitabelerinden tesbit etmek mümkündür. Bu yazitlarda kagan ve begler, Türk milletine yaptı̆̆ yardımlardan dolayı, Tanrıyı içten gelen minnet ve şükranlarla anmaktadırlar. Türk kaganlarına siyasi hakimiyetin temeli olan kut Tanrı tarafından verilir. Tann izin verdiği için düşmanlar perişan edilmiş ve devlet sahibi olunmuştur. Kitabelerde birçok yerde zikredilen Tengri'ye bazan Türk Tengrisi șeklinde de tesadüf edilmektedir. O zaman milli bir hüviyeti ortaya çıkıyor. Börülülerin (Aşinaların) hanedanlık kurmalan Tanrı tarafından olmuştur. Bumın ile Istemi'yi Tann tahta çıkarırken, Türk milleti yok olmasın diye İlteriş ile İlBilge Katun'u halk içerisinden çekip, yükselten O'dur. Halk kaganı terkettiği zaman Tanrı onlan cezalandırmıştır. Savaşlar onun sayesinde kazanılmısțr. Tanrı Kut'a ve Ülüg'e layı olmayanların elinden de bunları almıştır ${ }^{55}$. Yani Tann Türk milletinin geleceğini belirleyen en yüce varlıktır.

Bütün bunlar Tanri'nın eşi ve benzeri olmayan, insanlara yol gösteren, onların varlıklarma hükmeden bir Ulu yaratıcı olduğunu göstermektedir. Açıkça görülmektedir ki, bu semavi Tann inancının Şamanik düşüncelerle hiçbir alakası yoktur. Şurası da bir gerçektir ki, ne Şamanizm, ne de diğer Hak dinler Türk'ün bu milli dinine etki yapamamış, yani onu kendi gayelerine hizmet edecek şekle sokamamışlardır.

8. yüzyılda Hazar Türklerinin "bir yaratıcı Tanrı" tanıdıkları, hrıstiyanların "üçliu inancma" karşılık, onların tek Tannya iman ettikleri kaynaklarda yazılıdır. Hazar hükümdarı Bizanslı misyonerleri kabulünde, onlara çok ilgi çekici bir cevap vermektedir: "Bizler sizinle aynı düsüncelere ve inançlara sahibiz, ancak aynı yerde durmuyoruz. Siz Baba-Oğul-Kutsal Ruh'a inanır ve onun için çalışırken, bizler sadece tek Tanrı için çalışırız" demektedir. 10. yủzyılda bazı Türk boyları arasında dolaşan İbn Fadlan, Oguzların içlerinden biri zulme uğrar veya sevmediği birşey görürse başını semaya kaldırıp "bir Tanrı" dediklerini söylemektedir".

Dini itikad olarak varlığımın m.ö. 5. yüzyıla kadar indiği söylenen Kök Tengri'nin Asya Hunları arasında bile tek bir ulu varlığı temsil ettiği kayıtlıdır. Gökyüzündeki tabiat varlıklarının büyük rol oynadı̆g eski halk dinlerinde güneş, ay ve yıldızlann tanrı olarak tanınmalarına karşılık, Türkler gögüü bütün olarak sembolleştirmişler ve Kök Tengri itikadı ortaya çıkmıştır. Bu yüzden

"s.Gömeç, "Drevnyaya Religiya Tyurok", Şamanizm Kak Religiya: Genezis, Rekonstruktsiya, Traditsii, Yakutsk 1992, s.20.

${ }_{55}^{5}$ Gömeç, "Eski Türklerde Siyasi..., s.113-115.

"A.Zajaczkowski, "Khazarian Culture and Inheritors", Acta Orientalia, Tom. XII, Budapest 1961, s.302; R.Şeşen, İbn Fazlan Seyahatnamesi, İstanbul 1975, s.31. Zajaczkowski, Hazar Türklerinin, Karaim mezhebini kabul etmelerini tamamen bir siyaset olarak görmektedir. Onların komşuları olan Hrtstiyan ve Muislümanlara muhalefet amacıyla bu inanca girdiklerini, Arap ve Bizans etkisine karşı bir oyun olduğunu, bu inancın Hazar Kaganlığında gerçekten benimsenmediğinin altını çizmektedir (Bakınız, Zajaczkowski, a.g.m., s.302). 
bu inanç sistemi sadece Türklere özgüdür. Kök Tengri yalnızca kendisine itaat edilmesi gereken, koruyucu bir kudret olduğu halde, diğer varlıklar (güneş, ay, y1ldızlar) için önemli bir fonksiyon mevcut değildi. Mesela Bizans kaynaklarında, Kök Türkler ülkesinde Kök Tengri’nin tek yaratıcı varlık olduğuna; Türklerin ateş, su gibi bazı şeylere kutsallık atfetmelerine rağmen, ancak yer ve gögüun yaratıcısı Tanrı'ya taptıkları kaydedilmiştir.

Dinler tarihinde tesbit edilen bir hususa göre, hiçbir din saf halde kalmamıs, Tann herzaman kutsal sayılan ikinci derecede yan varlıklar ile çevrili bulunmuştur. Tarihin en büyük dinlerinde durum böyledir. Hrıstiyanlıkta bir yerine üç olan Tanrı kişiliğinden başka, Meryem Ana, melekler, azizler ve ölü ruhlan kutsaldır. Islamiyette, İhlas Suresi'nde "Allah'ın birliği ve vasıfları din felsefesi ve edebiyatında görülmemiş bir şekilde belirtilmiş" olduğu halde Amentiu Suresi'nde peygamberlere, kitaplara, meleklere iman vardır.

Kök Tengri dininin Türklere mahsus bir inanç olduğu Tanrı kelimesinden de anlaşılmaktadır. Bu kelime bütün Türk dillerinde olduğu gibi, Türkçeden birçok Asyalı kavmin diline de geçmiştir. Eski Türkçedeki Tengri kelimesi bugünküi çeşitli Türk lehçelerinde, her lehçenin fonetik özelliklerine göre tengri, tengere, tangrı, tangara, ture şekillerinde söylenir. Türkçenin asli kelimesi olan Tann'ya yazılı kayıt olarak, en eski m.ö. 3. yüzyılda rastlanmaktadır. Hiç şüphesiz bundan öncede mevcut idi. Zamanımızdan 2500 yil evvel, başta eski Yunanlılarda olmak üzere ölümlü ve ölümsüz birçok tanrının oldugunu görenler, Türklerde tek bir ilahın ve yaratıcı yerine geçen Tanr kelimesinin varlığına inanmamışlar ve bunu kabul edememişlerdir. Çinlilerin Türklerden aldığı kesin olan bu kelime eski kayıtlarda (m.ö. 5. yüzyıl) T'ien şeklinde, Tann manasına kullanılmıștır. Yani Türkler Tann'yı dinlerinin en yüksek varlığı olarak kullanmışlardır ${ }^{37}$. Altaylı kamlar Tann'ya dua ederken "yüksekte bulunan büyük atamız tengere, yaratıkları yaratan tengere, yildızlarla dünyayı süsleyen tengere" diye hitap ederler. Eski Türkçede "gök" (sema) ve "en büyuik yaratıcı" mefhumları tek bir kelimeyle ifade edilmiştir. islam dinini kabul eden Türkler ise gök kelimesini sema, tengri kelimesini de "Allah" mefhumuna tahsis ettiler. Eski Türkçede hava anlamina gelen "kalıg", İslamdan sonra "gök-sema" manasına kullanılmak istenmişse de, tutunamayarak, sonraları büsbütün unutulmuştur. Tanrı kelimesı yerine Oguzlann kullandığı "çalap" terimi de yaşama imkanı bulamadi.

Günümüzde yaşamaya çalışan eski Türk dininin zaman zaman ıslah edilmeye çalışıldığını görmekteyiz. Son teşebbüs 20 . yüzyılın başında Altay Dağlarında görüldüi. Bu harekete dünya literatüründe Burhanizm denmektedir. Altay Türkleri ise $A k-Y$ ang (Ak din) demişlerdir. Bu hareket yalnız bozulmuş Şamanizme karşı değil, Rus emperyalizmine karşı da bir baş kaldırı idi.

Burhanizmin kesin başlangıç tarihi belli değildir. Ancak bu inancın Rus hükümeti tarafından ortaya çikarılması 1904 yılının başlarına rastlar. Bu itikadın temeli bozulmus, yani içerisine Budizm, Maniheizm ve sonra bazı semavi dinlerin karıştığı Türk dini ile Rus egemenliğine düşmanlıktır. Bununla beraber Burhanizm, Lamaizme bir geçiş olarak görüldüğü gibi, Şamanizm ile

${ }^{\nabla}$ Kafesoğlu, Eski Türk Dini, s.22-66; H.Tanyu, İslamlıktan Önce Türklerde Tek Tanrı İnancı, Ankara 1980, s.15-19; Çavuşoğlu, a.g.m., s. 28. 
Hrıstiyanlığın da bir çatış̧ması şeklinde değerlendirilmektedir. Ancak Burhanizmin çıkışının temelinde, hernekadar eski Rus yazarlar birtakım feodal düzen emarelerine işaret ediyorlarsa da, yüz yıllık belki de ikiyüz yıllık rahatsızlıklar yatmaktadır. Ruslar gelene kadar kendi topraklarını ekip biçebilen, hayvanlarını bozkırlarda hürce otlatabilen Türk halkının elinden bu gibi imtiyazları alınmış, üstüne-üstlük binlerce yıldan beri üzerinde atalarının yattı̆̆ topraklara Rus göçmenleri getirilerek yerleştirilmişti. Aslında Burhanizm hareketine dinî vasfinın yanında, millì bağımsızlık ayaklanması olarak da bakmakta fayda vardir.

Burhanizmin belki ilk şeyhi diyebileceğimiz kişi Altaylı bir Türk olan Çet-Çelpen'dir. Karısı ile beraber, 14 yaşında bir kız evlatlığı olan bu Türk Úst-kan kasabasından $20 \mathrm{~km}$ uzaklikta bulunan bir ormanlık bölgede yaşıyor ve burada ibadet ediyordu. Yanına gelenlere bu Ak-yang' in ilkelerini ögretiyor ve nasihatlarda bulunuyordu. Çet-Çelpen'in ögrretisine göre, Ruslarla beraber yemek yemek, onlarla dost olmak yasaktı. Hatta Rus parası bile kullanılmamalıydı. 20. yüzyılın kamları Kök Tengri Dininin içine birçok akla ve mantığa sığmayan hurafeler soktukları için onlar şeytan işleriyle uğraşıyorlardı. Onların davullarını, cübbelerini ve asalarını ateşte yakarak gerçekleri görmeye zorlamak lazımdı. Tanriya hoş kokulu otların dumanı, süt, şarap ve kımız gibi saçılar da kurban sayılabilirdi. Eğer bu din etrafında birleşirlerse, Rus zulmünden de kurtulmak mümkün olacaktı.

Çet-Çelpen bütün vaazlarını çok güzel bir hitabeti olan kızı vasıtasıyla yapıyordu. $\mathrm{Bu} \mathrm{kızı}$ dinlemek için binlerce kişinin toplandığ 1 oluyordu. Zamanla Çet-Çelpen'in onbinlerce taraftarı oldu. Bu Rus hakimiyetinin Altaylarda tehlikeye girmesi demekti. Rusya'yı Burhanistlere karşı harekete sevkeden nedenlerden birisi de; bölgede faaliyet gösteren hrıstiyan misyonerlerin suçlamalarıyd. Misyonerler Burhanizmi kendi çalışmalan için yeni bir düşman olarak gördüler. Onlar yazdıklan yazılarda veya devletin merkezine gönderdikleri haberlerde hayali Japon ajanları arayarak, halk arasında bir Japonseverliğin var olduğunu ispatlamaya çalışıyorlardı. Hem Mogol Lamalarının zarar verici faaliyetleri, hem de Burhanistlerin Japon taraftarlığından söz ederek, onlara karşı bir cephe oluşturdular. 1904 temmuzunda binlerce Altay Türkü tören için Çet-Çelpen' in çadırı etrafında toplanmışlar, genç kızın ateşli nutkunu ve ilahilerini dinlerlerken, ibadetle meşgul bu silahsız insanlar Rus askerleri tarafından baskına uğradılar. ÇetCelpen, karısı, kızı ve ileri gelen yirmi kadar müridi tutuklandı. Rus hükümeti Ãltaylı Burhanistlerin mallarmı ve mülklerini yağmaladı. Çet-Çelpen ve arkadaşları ağır ceza mahkemesinde yargılandılar. $\mathrm{O}$ zaman Rus devlet dumasında bulunan bazı liberal görüşlï kişiler ve avukatlar onların savunmalarını üstlendiler. Böylece ölüm cezasından kurtuldular ${ }^{58}$. İki yıl sonra Çet-Çelpen Biysk hapisanesinde öldü. Burhanizm hareketi böylece sona ermiş oldu.

§i Ínan, a.g.e., s.201-203. Burhanizm için bakını, A.G.Danilin, Burhanizm, GornoAltaysk 1993. 